\title{
胃液分泌にかんする臨床的ならびに実験的研究 特にCl一の変動を中心として
}

\author{
大䛀医科大学内内科学数寉（指学岩田策雄教授） \\ 朝倉晃
}

\section{CLINICAL AND EXPERIMENTAL STUDY ON SECRETION OF GASTRIC JUICE, PARTICULARLY ON VARIATION OF $\mathrm{Cl}^{-}$}

\author{
Akira Asakura \\ Department of Internal Medicine, Osaka Medical College \\ (Director: Prof. Shigeo Iwata)
}

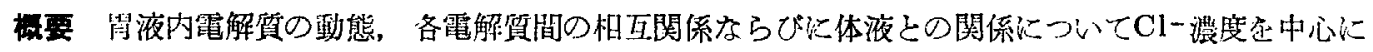

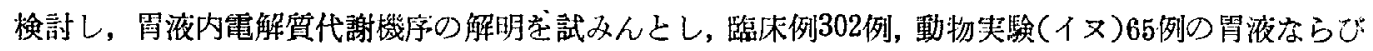

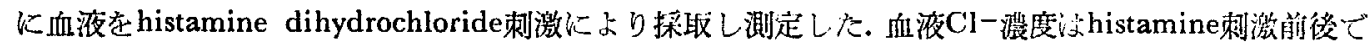

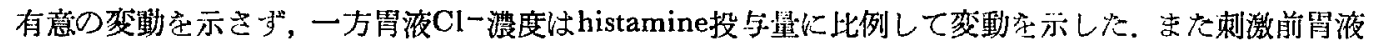

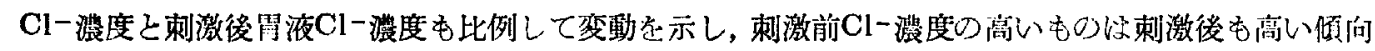

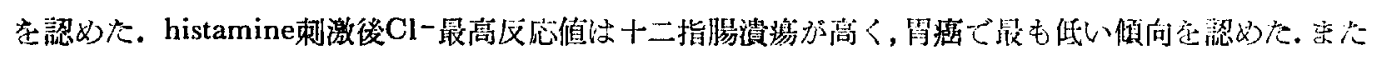

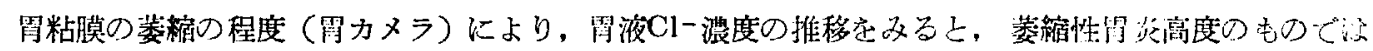

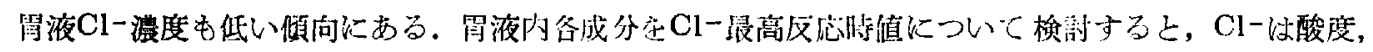

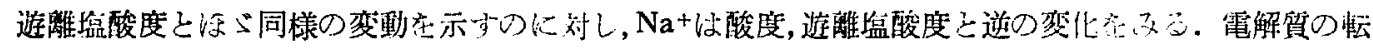
送に関係があるといわ礼る各種蒋物 (acetazolamide, chlorthalidone, prednisolone, spironolactone,

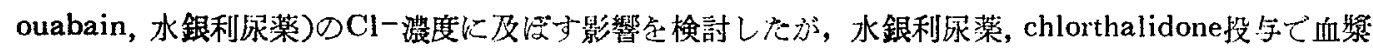

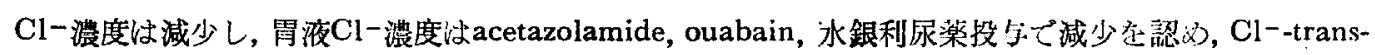

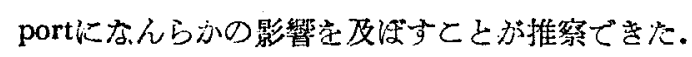

\section{I. 粕 言}

胃液中に塩酸をはじめ，種々の成分の存在が認 められているが，胃壁各腺細胞の分泌機構ならび に吸収機構の有無について種々の説がある.

胃液の大部分をしめる塩酸の分泌機構にかんし ては，19世紀に胃液中に塩酸の存在が認められ， 一方Heidenhain, Langleyらにより壁細胞よりの 塩酸分泌が唱えられた。また塩酸構成分子の $\mathrm{H}+$ にかんしては，壁細胞の炭酸脱水素酵素（以後 CA と略す) が関与している事を1938年にDavenport ${ }^{15}$ が明らかにし， 胃壁細胞の細胞生理解明の
糸口となつた。今日一般的に想められている塩酸

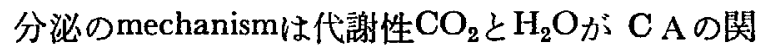
与により $\mathrm{H}_{2} \mathrm{CO}_{3}$ となり, $\mathrm{H}_{2} \mathrm{CO}_{3} の \mathrm{H}+$ が 特異的に ある運搬体 (carrier) と結合し，壁細胞小管部に 運ばれ，別のmechanismで運ばれて来た $\mathrm{Cl}$ 一結 合し $\mathrm{HCl}$ として胃液中に分泌されるとしたもの である。しかしCl一の血液より胃壁への移動の mechanism抢よび胃壁における移動にかんしては 末解決の点が多い.

血液および胃液 $\mathrm{Cl}$ 一濃度の関係については，古 くからRosemann"2), Cahn, Pollandらの 報告が孚 
られ，本邦的おいても三种，梅野，村松らの知見 が誌められる。また近年虍射性同位元素の発達と ともに胃壁の分泌，吸収の研究にisotope 使用し た, Hogben ${ }^{3)}$, Heinz, Cooperstein ${ }^{4}$ らの知見が認 められるが，腺細胞の分泌機構そのものの解明に は至つていない。

最近腎を含む腺細胞の電解質代謝がかなり解明 されるに至つて，消化管の電解質の動態に注目さ

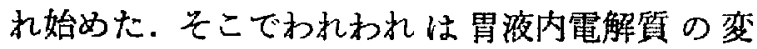
動, 各電解質間の相互関係, 体液間の動態ならび に各種酵素の活珄之電解質との関係，さらに胃粘 膜像と電解質の関係を臨床的ならびに実験的に検 部し，雷液分泌機序の解明を試从んとした。

本研究では胃液総 $\mathrm{Cl}^{-}$濃度を中心とし, 血液 $\mathrm{CI}$ 濃度，ならびに酸度，遊離壏酸度， $\mathrm{Na}^{+}, \mathrm{K}+$ 等等 液内成分已の相互関係化ついて倹討した。

I. 研究対象, 項目ならひにに方法

炤和38年10月ょり昭和40年 9 月まで，本学附属

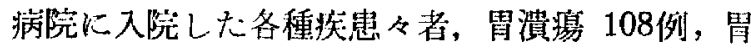
嵒43例，十二指腸潰瘍24例，之0)他胃疾患（胃炎， 胃良性腫港等）32例，貧血19例，腎疾患21例，朋 - 胆道疾患16例，膵炎，動脈硬化，寄生虫疾患， 内分泌疾患等 16 例に正常 23 例を加克て計 302 例を 臨床実験の対照とした。

胃夜採取は前日上り薬物の投与を中止し，早朝 空腹時に刺激薬として $0.1 \%$ histamine dihydrochloride (以後histamine剌激と略す) $0.01 \mathrm{mg} / \mathrm{kg}$, $0.02 \mathrm{mg} / \mathrm{kg}, 0.03 \mathrm{mg} / \mathrm{kg}, 0.04 \mathrm{mg} / \mathrm{kg}$ のいずれかを 皮下注射し, 注射前15分（以後前液，前 1 と仮称 す), 注射直前（以後基礎分泌液，前 2 と仮称す） 胃液を採取し，注射後は15分間隔に 120 分間の 胃液をRehfuss管を用いて採取し，胃液分泌量， 総酸度, 遊䧻塩酸度, $\mathrm{Cl}^{-}, \mathrm{Na}+, \mathrm{K}+$ の測定に供 した。 また基礎分泌時ならびにhistamine刺激15分 後の肘静脈血と，胃液採取終了後の股動脈血を， heparin添加注射器に採取し, 全血はTungsten酸 法で除蛋白したものを，血整は遠心分離したもの を $\mathrm{Cl}$ 一濃度の測定に供した。

一方, 対照としてhistamine刺激を加えずに 135
分間胃液を分画採取し，血液は第 2 回目ならびに 第 3 回目胃液採取時の肘静脈血々胃液採取終了後 の股動脈血を測定に供した。

体液電解質の転送に関係があるといわれている 各種薬物の胃液ならびに 血液 $\mathrm{Cl}$ 一湮度一の影響を みるために，胃潰瑒患者を主体に40名の患者に対 し 1 週間の間隔を置いて 2 回胃液の採取を行なつ た。第 1 回目は薬物投与を行なるずに胃夜ならび に血液を採取し，対照とした. 第 2 回目は各種薬物 をあらかじめ投与し，第 1 回目同様に胃液および 血液を採取した。な业薬物の胃液基礎分泌への影 響をみるために原則としてhistamine刺激前 120分 間（以後基礎分泌期と仮称す）の胃液も採取した.

使用した楽物，投与量，投与方法は次のごとく である。

1) acetazolamide

a) acetazolamide 500 mg 午前 0 時，5時の2 回に分服

b) acetazolamide $1000 \mathrm{mg}$ 午前 0 時，5時の 2 回以分服

2) spironolactone; spironolactone $100 \mathrm{mg}$ 午前 0 時，5 時の 2 回に分服

3) chlorihalidone; chlorthalidone 150mg 前日 午後 9 時，当日午前 0 時，5時の 3 回に分服

4) prednisolone; prednisolone 30mg 前日午後 9 時, 当日午前 0 時, 5 時の 3 回に分服

5）水銀利尿薬； chlormerodrin 1 筒（有機水 銀利尿薬 $130 \mathrm{mg}$ ) 午前 5 時に筀注

動物実験は $5 \sim 15 \mathrm{~kg}$ の成犬にpentobarbita1 sodium麻䤃下で胃瘦を作製し，刺激薬として， histamine $0.1 \mathrm{mg} / \mathrm{kg}$ を注射し， histamine刺激前 2 回，刺激後は90分までの胃液を持綾分画採取し， 湘定に供した。

血液は殷動脈上り，基礎分泌時， histamine刺激 後15分, 45分, 75分にheparin添加注射器にて採取 し、それぞれ全血，血浆に分離し，測定に供した。動 物実験では薬物の 影響をみるためにhistamine単 独使用10例を対照とし，各種薬物 とhistamine併 用群（1 群 5 例）と此較した。本動物実験に使用 
した薬物，投与量，投与方法は次の如くである．

1) acetazolamide; acetazolamide 1000mg を胃 液採取 180 分前に皮下注射

2）水銀利尿薬；Igrosin 1 筒（有梂水銀利尿薬 100mg）を胃液採取60分前に静脈内注射

3） prednisolone; prednisolone 50mg（水溶性） を胃液採取 60 分前に静脈内注射

4） ouabain; ouabain $0.075 \mathrm{mg}$ 胃液採取60分 前に静脈内注射

测定方法

血液おょよ゙胃夜 $\mathrm{Cl}$ 一濃度はSchales and Schales 法を, 総酸度ならびに遊離塩酸度はTöpfer-Michaelis法により, $\mathrm{Na}+, \mathrm{K}+$ 濃度はColeman21型炎光 光度計にて21-207 Na-filterおよび21-203 K-filter を用い測定した。

なお本研究には推計学的検討を試みたが，測定 值の表示には，平均值士標準偏差を用い，差の有 意性，相関係数の有意性の検定は，有意水準 $5 \%$ を用い $\mathrm{t}$ 検定を行なつた。

\section{III. 研究成績}

1) histamine刺激による血淮ならびに胃液 $\mathrm{Cl}$ 濃度の変動

従来，胃液分泌機能の検查には種々の刺激薬が 使用されており，中でもKatsh u. Kalkが発表した たcaffeineによる刺激法が多く用いられていたが， 胃液そのものが得られ，また刺激力の点で注射に よる方法に変りつつある，注射による刺激法と しては insulin法, imidaline法, histamine法, acetylcholine法, histalog法等があるが，中でも histamineは刺激力が強く, 神経因子を除外して腺 細胞の働きそのむのを表現し得るといら点で最も 良く使用されている、Kay ${ }^{5)}$ らの報告する maximal acid outputといわれるhistamine刺激量と腺細胞 の反応態度について目本人胃液ではどのような反 忘を示すか，また胃液としての水分泌，電解質分 泌, 醭分泌, 粘液分泌等をつかさどる胃壁の障 害の範囲，程度により，胃液成分にどのような影 響を及ぼすかを知ることが，胃液分泌を理解する 上に重要である。

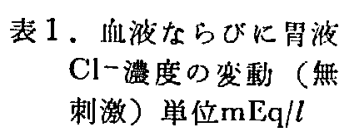

表 1 、扎波ならびに胃波

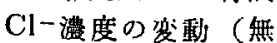
刺激) 単位 $\mathrm{mEq} / l$

汶2。Histamine剌激に よる低渡ならびに胃 波 $\mathrm{Cl}$ - 澹度の変䡃 単位 $\mathrm{mEq} / \mathrm{l}$

\begin{tabular}{|c|c|c|c|c|c|c|c|}
\hline & 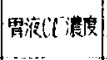 & 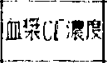 & 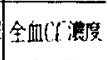 & & 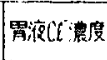 & 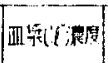 & 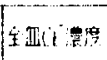 \\
\hline 㨁後 & $|111.1 \pm 14.0|$ & & & 前。 & $90.5 \pm 21.8$ & & \\
\hline $15^{\prime}$ & $105.8 \pm 3.1$ & $100.2 \pm 9.0$ & $75.7 \pm 10.0$ & 前 & $96.2 \pm 20.0$ & $105.2 \pm 10.0$ & $75.8+11.0$ \\
\hline $30^{\circ}$ & $107.5 \pm 18.0 \mid$ & $100.7 \pm 7.1$ & $77.3 \pm 11.0$ & 16 & $\mathrm{WW}_{5} \pm 23.0$ & $10 . .1 \pm 6.1$ & $14.4 \pm 6.8$ \\
\hline $45^{\circ}$ & $111.2 \pm 13.0$ & & & $30^{\circ}$ & $167.7 \pm 42.7$ & & \\
\hline $60^{\circ}$ & $102.5 \pm 20.0 \mid$ & & & $45^{\prime}$ & $114.2 \pm 25.0$ & & \\
\hline $75^{\prime}$ & $48.3 \pm 28.0$ & & & $60^{\circ}$ & $109.9 \pm 24.0$ & & \\
\hline $90^{\circ}$ & $100.1 \pm 31.0$ & & & $75^{\prime}$ & $106.5 \pm 24$. & & \\
\hline $105^{\prime}$ & $91.2 \pm 52.3$ & & & $90^{\circ}$ & $102.8 \pm 20.0$ & & \\
\hline $120^{\circ}$ & $96.1 \pm 36.8$ & & & $105^{\prime}$ & $99.1 \pm 28.1$ & & \\
\hline $135^{\prime}$ & $94.9 \pm 33.2$ & $104.5 \pm 8.6$ & $73.7 \pm 6.7$ & $120^{\circ}$ & $98.4 \pm 22.0$ & $106.1 \pm 14.0$ & $77.4 \pm 4.6$ \\
\hline
\end{tabular}

ヘ）胃ゾンデ挿入による血液ならびに胃液 $\mathrm{Cl}$ 濃度一の影響（表 1 )

胃腺科胞のhistamine飞よる反応態度を検討す る前に対照として, 胃ゾンデ挿入後, 刺激薬投与 を行なわずに 135 分間胃液を分画採取し，血液 $\mathrm{Cl}$ 一濃度ならびに胃液総 $\mathrm{Cl}$ 一濃度（以後胃液 $\mathrm{Cl}$-濃 度と略す）の推移を観察した。

血液 $\mathrm{Cl}$-濃度はゾンデ挿入中，ならびに抜去後 とも变動を認めない，胃液 $\mathrm{Cl}$ 一濃度はゾンデ挿入 直後 $111.1 \pm 19.0 \mathrm{mEq} / l$, 挿入後 45 分間はや>高

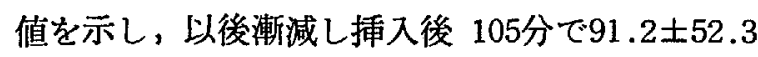
$\mathrm{mEq} /$ /を示す．最高平均值と最低平均值との間で 推計学的検討を行なつたところ, 両者の間に有意 の差を認めない $\left(t_{0.05(18)}=1.18\right)$.

B） histamine刺激による血液ならびに胃液 $\mathrm{Cl}$ 濃度の変動（表 2 ）

胃液 $\mathrm{Cl}$-濃度は前液 $95.0 \pm 21.8 \mathrm{mEq} / l$, 基礎分泌 特 $98.2 \pm 20.0 \mathrm{mEq} / l$ を示し, histamine剌激により 急激に增加し, 刺激後 45 分で $114.2 \pm 25.0 \mathrm{mEq} / l$ と最高值を示し，以後なだらかに減少し，刺激後 120 分で $98.4 \pm 22.0 \mathrm{mEq} / l$ と基礎分泌值まで低下 する。 
基礎分泌時ならびにhistamine刺激15分後の 血l 液 $\mathrm{Cl}$-濃度の变動を恰討すると，平均值では，血 浆, 全血とも刺激15分後で減少を認めたが, 推計 学的に検討したところ, 血浆 $\left(\mathrm{t}_{\mathbf{0 . 0 5}(122)}=1.00\right)$, 全血 $\left(\mathrm{t}_{0.05(122)}=0.14\right)$ ，とも有意差を認めない.

$\mathrm{Kay}^{5)}$ らの実験によるとリン酸ヒスタミン0.04 $\mathrm{mg} / \mathrm{kg}$ 投与で胃液分泌の最大反応㑑を認めてお り，教案においてもhistamine投与量を変えて胃液 内成分の反応棣相を観察した忠田 ${ }^{6)}$ の報告でも histamine $0.04 \mathrm{mg} / \mathrm{kg}$ で最大反応值を認めている. そこでhistamine投与量と胃液 $\mathrm{Cl}$-濃度の分泌様相 との関係を検討した（表 3 ）.

Histamine $0.01 \mathrm{mg} / \mathrm{kg}$ 投与例の胃液 $\mathrm{Cl}$-濃度は基 礎分泌值 $92.0 \pm 16.0 \mathrm{mEq} / l$, histamine刺激後 30 分 で108.9土30.2mEq/lに達し, 以後急激に減少し, 刺激後120分で75.0土59.7mEq/lを示す. histamine $0.02 \mathrm{mg} / \mathrm{kg}$ 投与例では基礎分泌 $89.0 \pm 17.0 \mathrm{mEq} / \mathrm{l}$, 最高值は刺激後45分で $101.2 \pm 23.0 \mathrm{mEq} / \mathrm{l}$ を示し, 刺激後 120 分で $93.2 \pm 23.0 \mathrm{mEq} / \mathrm{l}$ を示す. histamine $0.03 \mathrm{mg} / \mathrm{kg}$ 投与例では基礎分泌 $102.5 \pm 22.0$

表 3 . Histamine是別胃液 $\mathrm{Cl}$-濃度の変動 単位 $\mathrm{mEq} / \mathrm{l}$

\begin{tabular}{c|c|c|c|c}
\hline & Histamine & Histamine & Histamine & Histamine \\
\hline 前, & $92.1 \pm 16.0$ & $89.7 \pm 18.0$ & $100.6 \pm 22.0$ & $94.2 \pm 23.0$ \\
\hline m. $_{2}$ & $92.0 \pm 16.0$ & $89.0 \pm 17.0$ & $102.5 \pm 22.0$ & $101.2 \pm 20.0$ \\
\hline $15^{\prime}$ & $105.9 \pm 25.2$ & $96.0 \pm 20.0$ & $107.5 \pm 24.0$ & $111.4 \pm 23.0$ \\
\hline $30^{\prime}$ & $108.9 \pm 30.2$ & $99.2 \pm 25.7$ & $166.8 \pm 23.0$ & $119.7 \pm 15.0$ \\
\hline $45^{\prime}$ & $100.5 \pm 29.9$ & $101.2 \pm 23.0$ & $118.4 \pm 33.8$ & $120.0 \pm 23.0$ \\
\hline $60^{\prime}$ & $83.7 \pm 28.4$ & $95.6 \pm 22.0$ & $114.8 \pm 21.0$ & $116.6 \pm 23.0$ \\
\hline $75^{\prime}$ & $80.6 \pm 32.4$ & $94.0 \pm 17.0$ & $108.6 \pm 26.7$ & $113.8 \pm 22.0$ \\
\hline $70^{\prime}$ & $85.6 \pm 28.7$ & $94.2 \pm 2.7$ & $104.7 \pm 20.0$ & $107.3 \pm 26.4$ \\
\hline $105^{\prime}$ & $66.0 \pm 33.8$ & $90.6 \pm 27.2$ & $104.5 \pm 21.3$ & $102.9 \pm 26.5$ \\
\hline $120^{\circ}$ & $75.0 \pm 59.7$ & $93.2 \pm 23.0$ & $100.6 \pm 12.0$ & $100.2 \pm 28.3$ \\
\hline
\end{tabular}

$\mathrm{mEq} / l$, 最高值は刺激後 45 分で $118.4 \pm 33.8 \mathrm{mEq} / l$ に達し, 刺激120分後で $100.6 \pm 12.0 \mathrm{mEq} / l$ を示 す. histamine $0.04 \mathrm{mg} / \mathrm{kg}$ 投与例では基礎分泌 101.2 $\pm 20.0 \mathrm{mEq} / l$, 最高值は刺激後 45 分で $120.0 \pm 23.0$ $\mathrm{mEq} / /$ に達し, 刺激後 120 分で $100.2 \pm 28.3 \mathrm{mEq} / \mathrm{l}$ を示す，一方 $\mathrm{Cl}$-最高反応值と基礎分泌值の差 (以 後 $\mathrm{Cl}$-変動幅, $\Delta \mathrm{Cl}$ - と仮称)について推計学的に 検討を行なつた。

Histamine $0.01 \mathrm{mg} / \mathrm{kg}$ 投与群では $\Delta \mathrm{Cl}^{-1}=12.8 \pm$ $26.8 \mathrm{mEq} / l$ で有意の変動を認めない（ $\mathrm{t}_{0.05(18)}=$ 1.06).

Histamine $0.02 \mathrm{mg} / \mathrm{kg}$ 投与群 $\Delta \mathrm{Cl}-=18.7 \pm 16.0$ $\mathrm{mEq} / l\left(\mathrm{t}_{0.05(72)}=7.69\right)$. histamine $0.03 \mathrm{mg} / \mathrm{kg}$ 投与 群 $\Delta \mathrm{Cl}-=20.7 \pm 17.5 \mathrm{mEq} / l\left(\mathrm{t}_{0.05(88)}=8.16\right)$. histamine $0.04 \mathrm{mg} / \mathrm{kg}$ 投与群 $\Delta \mathrm{Cl}^{-}=25.7 \pm 19.0$ $\mathrm{mEq} / l\left(\mathrm{t}_{0.05(90)}=9.17\right)$ を示し, それぞれ基礎分泌 值に比べ変動を認めた.また $\Delta \mathrm{Cl}$ ーをhistamine投与 群別に比較すると, histamine $0.01 \mathrm{mg} / \mathrm{kg}$ と histamine $0.03 \mathrm{mg} / \mathrm{kg}\left(\mathrm{t}_{0.05}(51)=2.12\right)$, histamine 0.04 $\mathrm{mg} / \mathrm{kg}\left(\mathrm{t}_{0.05(52)}=2.94\right)$, histamine $0.02 \mathrm{mg} / \mathrm{kg}$ と histamine $0.04 \mathrm{mg} / \mathrm{kg}\left(t_{0.05(103)}=2.01\right)$ の間に有意差を 認め, histamine $0.03 \mathrm{mg} / \mathrm{kg} と 0.04 \mathrm{mg} / \mathrm{kg}$ の間に差を 認めない $\left(\mathrm{t}_{0.05(103)}=1.07\right)$.

小括. 対照として刺激薬投与を行なわすにに $\mathrm{Cl}$ 濃度の推移を検討したが, 胃液, 血液ともに有意 の变動を認めず，ゾンデ挿入による影響は少ない むのと思われる. histamine刺激で胃液 $\mathrm{Cl}$ 一濃度は 増加し, 刺激45分後で最高值に達し以後淵减す る. 血液 $\mathrm{Cl}$-濃度はhistamine刺激後15分で血浆， 全血とも平均值で減少を認めたが, 推計学的に有 意の差を認めない。

Histamine投与量別にCl-変動幅について 検討 した. histamine $0.01 \mathrm{mg} / \mathrm{kg}$ 投与群では変動少なく， 基礎分泌值に比べ変動を垫めず， histamine 0.02 $\mathrm{mg} / \mathrm{kg}, 0.03 \mathrm{mg} / \mathrm{kg}, 0.04 \mathrm{mg} / \mathrm{kg}$ 投与群では変動を認 めた，その反応態度は刺激量に比例して大となる が，一方histamine $0.03 \mathrm{mg} / \mathrm{kg}$ と $0.04 \mathrm{mg} / \mathrm{kg}$ の間に有 意の差を認めず，したがつて以後histamine 0.03 
$\mathrm{mg} / \mathrm{kg} ， 0.04 \mathrm{mg} / \mathrm{kg}$ 投与群を主体にして検剖を行な らことにした。

2）胃液 $\mathrm{Cl}$ 一濃度に上る分類

胃液Cl一濃度は胃ゾンデ挿入の影響をほとんど 受けないことがわかつたが, Lambling?は彼の分 画Bが胃腺の感受性を表現していると報告した。 そこで本実験で胃液基礎分泌值ならびに刺激後の 胃液 $\mathrm{Cl}$-濃度との関係，血夜と胃液 $\mathrm{Cl}$-濃度の関 保について検討した。

\section{A）胃液基碟分泌值 $\mathrm{Cl}$-濃度による分類}

基碟分泌值 $\mathrm{Cl}$-濃度により， $\mathrm{A}$ 群 $(\mathrm{Cl}-$ - $: 110$ $\mathrm{mEq} / \mathrm{l}$ 以上), B 群 $(\mathrm{Cl}-: 85.0 \sim 109.9 \mathrm{mEq} / l), \mathrm{C}$ 群 (Cl-:84.9mEq/l以下) に分け蒋液ならびに血 液 $\mathrm{Cl}$ 一濃度の推移について検討した。

基礎分泌時血淮 $\mathrm{Cl}$-濃度は $\mathrm{A}$ 群で血浆 108.5 土 $8.9 \mathrm{mEq} / l$, 全血 $69.7 \pm 10.0 \mathrm{mEq} / l . \mathrm{B}$ 群で血浆 108.1 $\pm 12.0 \mathrm{mEq} / l$, 全血80.7土 $6.2 \mathrm{mEq} / l$, C群で血浆 $107.3 \pm 4.5 \mathrm{mEq} / l$, 全血 $80.7 \pm 6.2 \mathrm{mEq} / l$ で, 各 群の間に血浆，全血とも有意の関係を認めなかつ た。胃液Cl一濃度は（図 1 の如く）A群では基礎 分泌 $122.6 \pm 12.6 \mathrm{mEq} / l$, 刺激後急激に增加し 45 分 で最高值 $136.3 \pm 16.7 \mathrm{mEq} / \mathrm{l}$ に達し, 以後急激に 隇少する。B 群では基礎分泌 $95.5 \pm 10.0 \mathrm{mEq} / l$, 刺 激後 30 分で最高值 $109.7 \pm 30.2 \mathrm{mEq} / \mathrm{l}$ に達し以後 漸減する。C群では基礎分泌 $74.2 \pm 17.0 \mathrm{mEq} / l$, 刺 激後 45 分で最高值 $93.1 \pm 22.8 \mathrm{mEq} / /$ に達し以後な だらかに滅少する。

\section{B ） $\mathrm{Cl}$-濃度最高反応時值による分類}

Histamine刺激後胃液 $\mathrm{Cl}$ 一最高反応時值により, $\mathrm{A}$ 群 $(\mathrm{Cl}-:$ : $130 \mathrm{mEq} / \mathrm{l}$ 以上), B 群 $(\mathrm{Cl}-:$ : $100.0 \sim$ $129.9 \mathrm{mEq} / l), \mathrm{C}$ 群 $(\mathrm{Cl}-： 99.9 \mathrm{mEq} / /$ 以下 $)$ 飞分け 胃液 $\mathrm{Cl}$ 一濃度の推移を倹討した（図2）。A群では 基碄分泌 $112.4 \pm 33.0 \mathrm{mEq} / l$, 刺激後45分で最高值 $134.3 \pm 9.6 \mathrm{mEq} / l$ 亿達し, 以後急激に減少する. B 群では基礎分泌 $92.0 \pm 20.4 \mathrm{mEq} / l$, 刺激後 30 分 で最高值 $105.6 \pm 10.2 \mathrm{mEq} /$ に達し，以後なだら かに減少する。，C群では基礎分泌 $79.6 \pm 35.6$ $\mathrm{mEq} / l$, 刺激後も $\mathrm{Cl}$ 一濃度は增加せず, 刺激 15 分後 $79.7 \pm 9.8 \mathrm{mEq} / l$ を示し以後漸減の傾向を示し

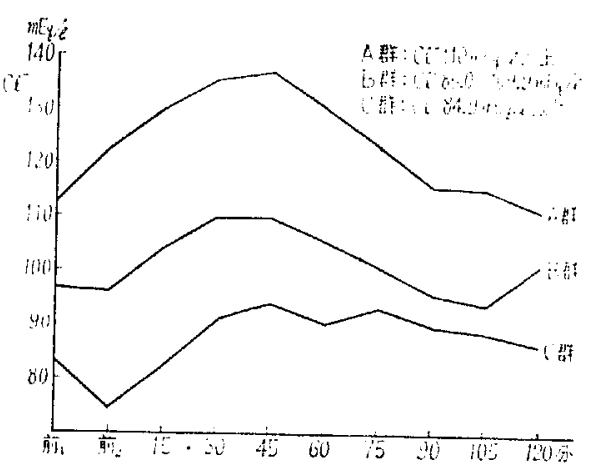

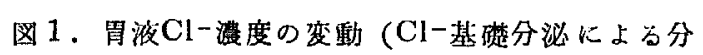
類)

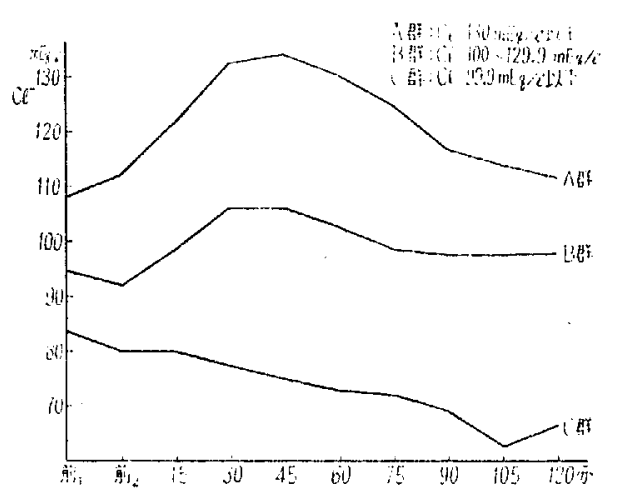

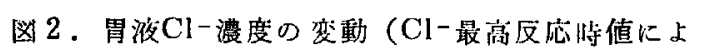
る分類）

た、C群に属すものはhistamine刺激に対し抵抗型 を示すものであり，その疾患分布をみると，胃潰 瘍 73 例中 15 例 $(15 \%)$, 胃癌 22 例中 6 例 $(27 \%)$, 正常 15 例中 2 例 $(13 \%)$, その他胃疾患19例中 3 例 (15 $\%$ ，消化管以外では貧血12例中 3 例 $(25 \%)$ が認 められ，十二指腸潰瘍では認められなかつた。

小括. 血液 $\mathrm{Cl}$-濃度と基礎分泌胃液 $\mathrm{Cl}$-濃度 と の間には有意の関係を認めない。一方胃液 $\mathrm{Cl}$-濃 度のhistamine刺激前後の関係を検討し, 基碟分泌 值の高いものでは刺激後も高く，基礎分泌值の低 いものでは刺激後も低い傾向を認めた。

3）胃液 $\mathrm{H}+$ 濃度に上る分類（図 3，4）

基礎分泌值とhistamine刺激後の胃液 $\mathrm{Cl}$ 一濃度と は比例して変動することがわかつた，そこで酸度 と $\mathrm{Cl}$ 一濃度との関係をみるために基礎分泌 $\mathrm{H}+$ 濃 


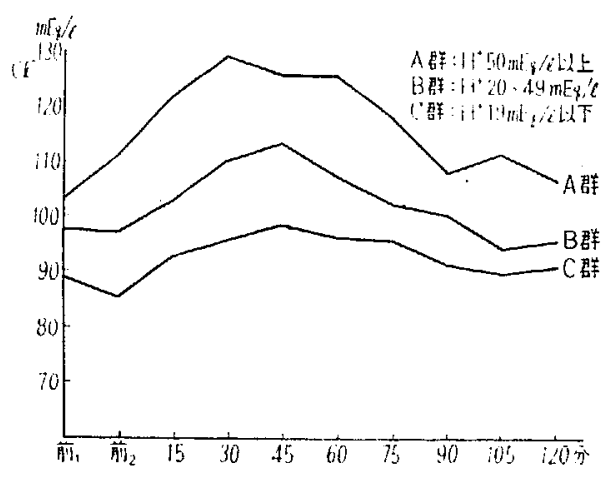

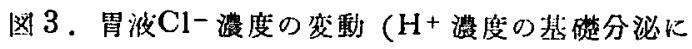
よる分頪）

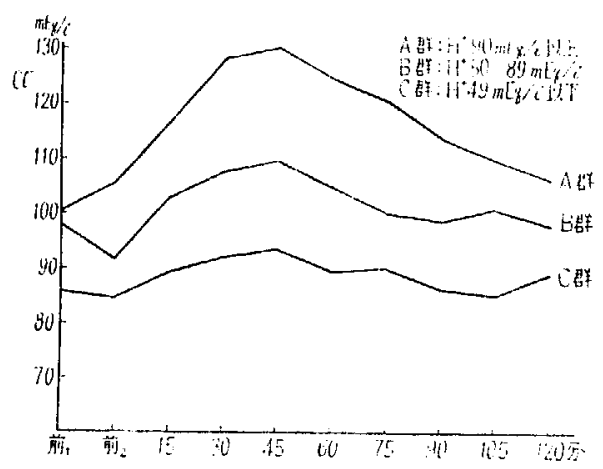

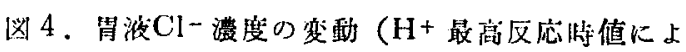
る分類)

度により $\mathrm{A}$ 群 $\left(\mathrm{H}^{+}: 50 \mathrm{mEq} /\right.$ 以上上 $), \mathrm{B}$ 群 $\left(\mathrm{H}^{+}: 20\right.$ 〜 $49 \mathrm{mEq} / l), \mathrm{C}$ 群 $\left(\mathrm{H}^{+}: 19 \mathrm{mEq} / \mathrm{l}\right.$ 以下) の 3 群に分 け胃液 $\mathrm{Cl}$-濃度の推移をみると, $\mathrm{H}+$ 濃度の高い屯 のはCl-濃度も高く, $\mathrm{H}+$ 濃度の低いものは $\mathrm{Cl}$-濃 度も低い傾向を認めた。一方胃液 $\mathrm{H}+$ 濃度最高反 応時值により, $\mathrm{A}$ 群 $(\mathrm{H}+: 90 \mathrm{mEq} /$ l以上 $), \quad B$ 群 $(\mathrm{H}+: 50 \sim 89 \mathrm{mEq} / l), \quad \mathrm{C}$ 群 $(\mathrm{H}+: 49 \mathrm{mEq} / \mathrm{l}$ 以下 $)$ の 3 群に分け, 胃液 $\mathrm{Cl}$ 一濃度の推移をみた. $\mathrm{H}+$ 濃 度最高反応時値の高いものでは基礎分泌值, 刺激 後ともに はCl一濃度も低い傾向を認めた。

4） histamine刺激に上る 各種疾患の胃液 $\mathrm{Cl}-$ 濃度の変動

Histamine刺激により胃液 $\mathrm{Cl}$ 一濃度は変動を示 し, その変動はH+濃度の高いるのでは $\mathrm{Cl}$-濃度も 高く, H+濃度の低いものではCl-濃度も低い傾向

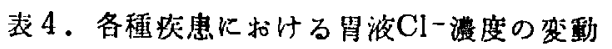
単位 $\mathrm{mEq} / \mathrm{l}$

\begin{tabular}{|c|c|c|c|c|c|c|c|c|}
\hline & 正常 & 甪謴港 & 男 疻 t & 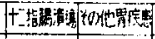 & 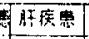 & 肾滨需 & $\mathrm{m}$ & 秘宗纺 \\
\hline 前， & $98.5 \pm 74.0$ & $|95.5 \div 30.4|$ & $93.7 \pm 17.0 \mid$ & $122.4 \pm 16.099 .8 \pm 177.0$ & $0|89.1 \pm 26.2|$ & $699.3 \pm 18.019$ & $90.5+16.0$ & $9938 \pm 12.0$ \\
\hline 前 & $|97.5 \pm 25.4|$ & $\mid 100.5 \pm 19.0$ & $|9: 4 \pm 200|$ & $9110.0 \pm 18.0996 .9+37.6$ & $6|92.9 \pm 23.0|$ & $096.8 \pm 28.98$ & $89.7 \pm 18.0$ & $1042 \pm 16.0$ \\
\hline $15^{\prime}$ & $10025 \div 45.5$ & $|00.6 \pm 22.0|$ & $|96, .9 \pm 22.20|$ & $=\mid 26.7 \pm 2.1 .0114 .6 \pm 26.5$ & $5.04 .6+18.0 \mid \mathrm{H}$ & $9 m .3 \pm 27.5$ & $|00.0 \pm 20.00|$ & $\sqrt{119.7 \pm 30.5}$ \\
\hline $30^{\circ}$ & $|112.1 \pm 19.0|$ & $|112.2 \pm 24.0|$ & $\| 06.1 \pm 23.31$ & $175.1 \pm \pm 16.01112 .9 \pm 25$. & $=|22.5 \pm 12.0|$ & $170 \pm 23.0$ & $|04.7 \pm 210|$ & $\sqrt{2127 \pm \pm 40.0}$ \\
\hline $45^{\circ}$ & $(24.9 \pm 26.3$ & $\mid 13.3+30.7$ & $710.5 \pm 19.011$ & $|132.1 \pm 200| 110.6 \pm 25.2$ & $2214 \div 140$ & $177.0 \pm 25.5$ & $\mid 05.8 \pm 2774$ & $172.3 \pm 27.4$ \\
\hline $60^{\circ}$ & $|166.1 \pm 21.0|$ & $|607.5 \pm 25.7|$ & $\mid 03: 422201$ & $|21.5 \pm 24.1| 12.4 \pm 23$ & $(19.2 \pm 16.0) \mathrm{n}$ & $173 . J \pm 28.3$ & (204.5228.0. & $126.1 \pm 33.9$ \\
\hline $75^{\circ}$ & {$[95.9 \pm 22.0 \mid$} & $|04.9+26.5|$ & $5 \mid 122.2 \pm 21014$ & $\mid 11.2 \pm 27,2107.1 \pm 26.89$ & $8 ; i 19.9+24,0$ & $\mid 106.4 \pm 26.1$ & $\mid 103.1 \pm 30.7$ & $120.7+22.0$ \\
\hline $90^{\prime}$ & $491.2 \pm 32.09$ & $98.9 \pm 23.0$ & $1025 \pm 18.0114$ & $|106.7 \pm 32.6| 103.5 \pm 25.8$ & $8111.7 \pm 19.0$ & $|080.6 \pm 29.0|$ & $92.1 \pm 28.7$ & $\overline{119.7 \pm 22.0}$ \\
\hline $105^{\prime}$ & $524 \pm 307$ & $100:: \pm 28.1$ & $99.9 \pm 306 ; 10$ & $103.0+26.800 .4+30.1$ & $|m 2.3 \pm 24.0|$ & $|106.2 \pm 24.0|$ & $91.0 \pm 2301$ & $115,0 \pm 16.0$ \\
\hline $120^{\circ}$ & $|85 . \pm 32.2|$ & $d x$ & 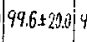 & $47.0 \pm 344996.8 \pm 2$ & & 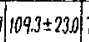 & 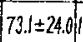 & $168+?$ \\
\hline
\end{tabular}

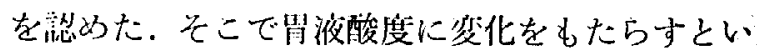

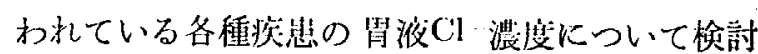
してみた。

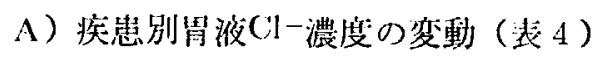

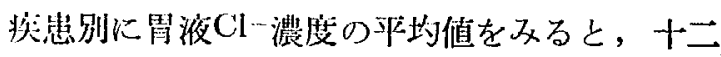

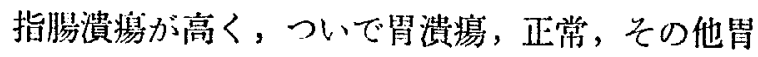
聅患, 胃癌の順に低下し，それ以外の疾患では筫 血，腎疾患の低值が認められるが例数执よび原疾 患の多様性のために除外し，十二指膆潰煌，胃潰 瘍, 胃癌, 正常例についてのみ推計学的検討を加 えた。基礎分泌值 $\mathrm{Cl}$-濃度について 各疾患間で推 計学的に検討したところ, 平均值で最高の十二指 腸潰瘍と最低の胃癌との問にも有意差を認めない $\left(\mathrm{t}_{0.05(27)}=1.36\right)$. histamine刺激後も十二指腸潰湯 ではCl-濃度は高く，変動も激しい，一方胃癌で は低い傾向をみるとこでCl一最高反応時值につ いて各疾患間を検討した。云指腸潰瘍（123.8 $\sim 158.8 \mathrm{mEq} / l$, 平均値 $141.3 \pm 14.6 \mathrm{mEq} / l)$ は最 も高く, ついで正常 $(81.0 \sim 151.8 \mathrm{mEq} / l$, 平均値 $132.4 \pm 12.0 \mathrm{mEq} / l)$, 胃潰演 $(63.2 \sim 179.4 \mathrm{mEq} / l$; 平均值 $128.7 \pm 16.0 \mathrm{mEq} / \mathrm{l}$ ) の順に低下し, 胃癌 $(82.9 \sim 136.3 \mathrm{mEq} / l$, 平均值 $111.5 \pm 21.0 \mathrm{~m} \mathrm{Eq} / l)$ は最も低い傾向を認めた。各疾患間について検討 したが, 胃癌と胃潰瘍 $\left(\mathrm{t}_{0.05(47)}=3.72\right)$, 胃癌と正 常 $\left(\mathrm{t}_{0.05(22)}=4.78\right)$, 胃癌亡十二指腸潰㾮 $\left(\mathrm{t}_{0.05(21)}\right.$ =7.01）の間に有意差を認めた。

B ) 随伴性胃炎之䏣液 $\mathrm{Cl}$-濃度 


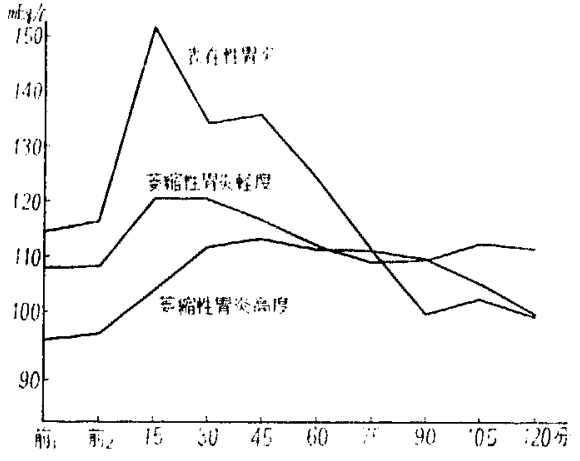

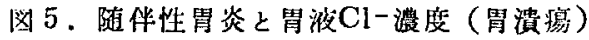

胃疾患の種類により胃液 $\mathrm{Cl}$ 一濃度の反応態度に 差のあることがわかつた。しかし同一垁患であ histamine刺激に 対して必ずしも同一の反応態度

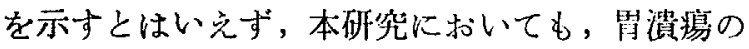
15\%にhistamine抵抗型を認妨。．そこで腺細胞の 分布する胃粘膜の状態を胃カメラ像から求め, 胃

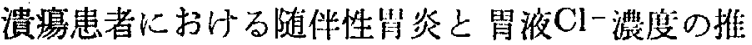
移を検討した（図 5 ）。

胃カメラで萎緶性胃炎の範囲ならびに程度の高 度のものでは胃液 $\mathrm{Cl}$-濃度は基礎分泌 $96.3 \pm 15.0$ $\mathrm{mEq} / l$, 刺激後最高值は 45 分で $113.0 \pm 14.0 \mathrm{mEq} / l$ に達する，萎縮性胃炎軽度で䇭囲も㹟いものでは 基礎分泌 $108.1 \pm 15.0 \mathrm{mEq} / l$, 刺激後 45 分で最高 值 $120.6 \pm 21.0 \mathrm{mEq} / \mathrm{l}$ に達する。表在性胃炎像を 示すものは，基礎分泌 $116.1 \pm 30.4 \mathrm{mEq} / \mathrm{l}$, 刺激 後15分で最高値 $151.5 \pm 30.4 \mathrm{mEq} / l$ に達する.

一方Cl一変動幅について随伴性胃炎各像を検討 したところ,萎縮性胃炎高度のものは $\Delta \mathrm{Cl}-=20.4$ $\pm 10.0 \mathrm{mEq} / l$, 萎縮性胃炎軽度のものは $\Delta \mathrm{Cl}^{-}=$ $23.6 \pm 21.0 \mathrm{mEq} / l$, 表在性胃炎では $\Delta \mathrm{Cl}-=25.7$ $\pm 16.0 \mathrm{mEq} /$ /になり，萎縮性胃炎高度のものでは 基礎分泌值, 最高反応時值ならびに $\mathrm{Cl}$-変動幅と も低い傾向を認める。

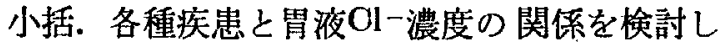
たところ，基礎分泌では疾患により差を認めず， 刺激後 $\mathrm{Cl}$-最高反応值に扣いては，十二指腸潰場 が最も高く,ついで正常, 胃潰瘍, 胃癌の順に低く なり，胃癌と他の疾患の間に有意差を認めた。ま
た胃潰瑒の随伴性胃炎と胃液 $\mathrm{CI}$-濃度の関係もみ たが，菱䋧性胃炎高度のもので基礎分泌， $\mathrm{Cl}$-㚆 動幅とも低く，表在性胃炎では高い偭向を認める。

5）胃液 $\mathrm{Cl}$-濃度と胃液内各成分の関係

胃液内電解質は $\mathrm{Cl}^{-}, \quad \mathrm{HCO}_{3}$-等陰 ion $\mathrm{C}^{+}$, $\mathrm{Na}^{+}, \mathrm{K}+$ 等陽ionとの間に互いに影響を受けなが ら分泌されるといわれているが，必ずしも各䉓解 質のhistamineに 対する反応態度が同じであると はいえない。この事は腺細胞の分泌能ならびに吸 収能を論ずるに重要な意味を有するものと思われ る。そこで基礎分泌と $\mathrm{Cl}$-最高反応時の差で胃液 内各成分の動態を検討した。

A) Histamine刺激による胃液各成分の㚆動

胃液各成分はhistamine刺激に上り变動し，その 变動を $\mathrm{Cl}$-変動幅で検討したが，胃液量 $\Delta \mathrm{Cl}-=$ $24.2 \pm 21.3 \mathrm{ml}, \mathrm{Cl}$-濃度 $\Delta \mathrm{Cl}-=22.1 \pm 18.0 \mathrm{mEq} / l$, $\mathrm{H}+$ 濃度 $\Delta \mathrm{Cl}-=30.9 \pm 39.3 \mathrm{mEq} / l$, 遊離塩酸度 (以 後 $\mathrm{F}-\mathrm{HCl}$ と略す) $\Delta \mathrm{Cl}-=39.1 \pm 34.0 \mathrm{mEq} / l$ 等は刺 激後增加し, $\mathrm{Na}+$ 濃度 $\Delta \mathrm{Cl}^{-}=-16.7 \pm 20.0 \mathrm{mEq} / \mathrm{l}$ と減少し, $\mathrm{K}+$ 濃度 $\Delta \mathrm{Cl}-=0.01 \pm 0.7 \mathrm{mEq} /$ は中有意 の変動を示さなからた。

一方histamine投与量別にその変動孛検討した が，胃液量はhistamine投与量に比例して変動幅も 增加し, $\mathrm{Cl}$-濃度と一致した変動を示し, $\mathrm{H}+$ と $\mathrm{Na}+$ 濃度の变動幅は histamine $0.01 \mathrm{mg} / \mathrm{kg}$ 投与群 で 最も大であり,F-HCl濃度は histamine $0.02 \mathrm{mg} / \mathrm{kg}$ 投 与群で変動幅が最も大である（表 5 ）。

B）各疾患儿上る胃液各成分の変動（表 6）

疾患別に胃液各成分の変動を基礎分泌 と $\mathrm{Cl}$-最 高反応時値の差で検討した。胃液量は $\mathrm{Cl}$-濃度と 同様の傾向を示し，十二指腸潰瑒が最も变動著明 で,ついで胃漬瘍, 正常, 胃癌の順で低くなる.H+ 濃度は正常が最も变動し,ついで十二指腸潰場, 胃 潰瘍, 胃癌の順で低下し, F-HClでは, 胃潰煌が 最も変動し, ついで正常, 十二指腸㵅煌, 垚癌の 順に低下した。Na+濃度では十二指腸潰瘍が变動 大きく, ついで胃潰瘍, 胃癌, 正常の順に低下し た、 $\mathrm{K}+$ 濃度は変動が少なく平均値ではNa+と同 様の順で低下した。 
小括. 罚液内各成分は histamine刺激後变動を 示したが，基礎分泌を原点とし， $\mathrm{Cl}$ 一最高反応時

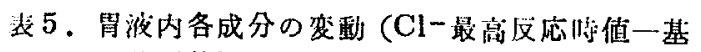
整分泌值)

\begin{tabular}{|c|c|c|c|c|c|c|}
\hline & $\mathrm{Cl}^{-}$ & 胃液 & $\mathrm{H}^{+}$ & $\mathrm{F}-\mathrm{HCl}$ & $\mathrm{Na}^{+}$ & $\mathrm{K}^{+}$ \\
\hline 栄位 & $m E_{g} / c$ & $\mathrm{ml}$ & $\mathrm{mEq} / \mathrm{s}$ & $\mathrm{mEq} / \mathrm{c}$ & $m E q / c$ & $m E_{q} / t$ \\
\hline $\begin{array}{l}\text { Histanise } \\
0.01 \times n / 4\end{array}$ & $12.8 \pm 26.8$ & $0.1 \pm 24.0$ & $38.8 \pm 39.5$ & $22.4 \pm 29.4$ & $-26.7 \pm 12.0$ & $1.1 \pm 2.4$ \\
\hline $\begin{array}{l}\text { Histanine } \\
0.02 \mathrm{~m} / \mathrm{m}\end{array}$ & $20.3 \pm 16.0$ & $0.2 \pm 15.0$ & $21.9 \pm 31.8$ & $42.2 \pm 40.9$ & $-12.7 \pm 23.0$ & $-0.6 \pm 3.1$ \\
\hline 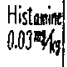 & $20.7 \pm 17.0$ & $10.5 \pm 26.3$ & $34.6 \pm 23.0$ & $37.7 \pm 29.8$ & $-13.0 \pm 18.0$ & $-0.4 \pm 3.9$ \\
\hline $\begin{array}{l}\text { Histanine } \\
0.04 \% \%\end{array}$ & $25.7 \pm 19.0$ & $11.3 \pm 18.0$ & $30.5 \pm 41.7$ & $39.8 \pm 33.7$ & $-23.0 \pm 28.7$ & $0.3 \pm 3.7$ \\
\hline
\end{tabular}

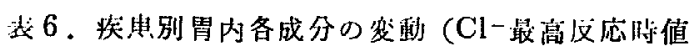
一基整分泌值）

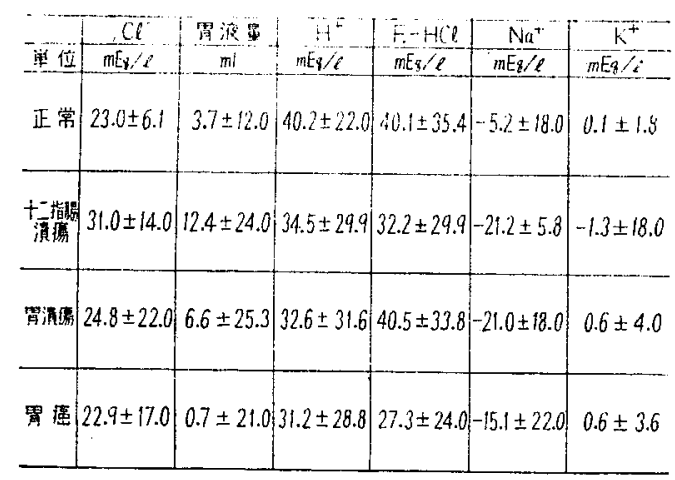

斐 7 , 胃液内各成分の相関性

\begin{tabular}{|c|c|c|}
\hline & 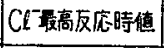 & $\mathrm{Cl}^{-}$变项幅 \\
\hline $\mathrm{Cl}^{-}: \mathrm{H}^{+}$ & $+0.64^{\circ}$ & $+0.48^{\circ}$ \\
\hline$C l: F-H C l$ & $+0.82^{\circ}$ & $+0.46^{\circ}$ \\
\hline $\mathrm{Cl}^{-}: \mathrm{Na}^{+}$ & -0.22 & -0.28 \\
\hline $\mathrm{H}^{+}: \mathrm{Na}^{+}$ & $-0.45^{\circ}$ & $-0.89^{\circ}$ \\
\hline $\mathrm{F}-\mathrm{HCl}: \mathrm{Na}^{+}$ & $-0.90^{\circ}$ & $-0.85^{\circ}$ \\
\hline $\mathrm{F}-\mathrm{HCl}: \mathrm{H}^{+}$ & $+0.86^{\circ}$ & $+0.69^{\circ}$ \\
\hline
\end{tabular}

值の胃液内各成分の変動幅について検討したが， 各成分は必ずしも $\mathrm{Cl}$-濃度変動と一致した態度を

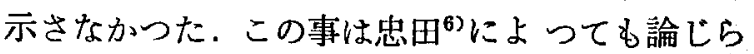
れているように，刺激住対する各成分の反応態度 が異なるためと解积できる。

6）胃液内各成分の相関

胃液内のCl一は各陽ion濃度の態度により結合 態度が異なつて来るものと考えられる。そこで胃 液内各成分の相関をCl一最高反応時值ならびに $\mathrm{Cl}$ 一变動幅について検討した（表 7 ）。

A） $\mathrm{Cl}$-最高反応時値における各成分の相関

Histamine刺激後 $\mathrm{Cl}$-最高反応時において $\mathrm{Cl}$-之 $\mathrm{H}^{+}$(図 6 ), $\mathrm{Cl}-$ - $\mathrm{F}-\mathrm{HCl}$ (図 7 ) , $\mathrm{H}+$ と $\mathrm{F}-\mathrm{HCl}$ (図 8 ）は正の相関を認め, $\mathrm{Na}+\xi \mathrm{H}+$ (図 9 ), $\mathrm{Na}+$ と $\mathrm{F}-\mathrm{HCl}$ (図10) は負の相関を認め, $\mathrm{Cl}$-と Na+ もまた負の相関の傾向を認めるが推計学的に有意 性は認めなかつた(図11)。 H+, Cl-およびF-HCl 濃度の間の相関係数を比較したが, それによると， $\mathrm{Cl}-$ は+ $\mathrm{H}+$ よ $\mathrm{F}-\mathrm{HCl}$ と高い相関を示し， $\mathrm{F}-\mathrm{HCl}$ と $\mathrm{H}+, \mathrm{F}-\mathrm{HCl}$ と $\mathrm{Cl}-$ 相関係数の間に有意差を認め なかつた。

B）基礎分泌值と $\mathrm{Cl}-$ 最高反応時值の 変動幅に お以る胃液内各成分の相関

基礎分泌值を原点にとり，刺激後 $\mathrm{Cl}$-最高反応 時との変動幅で各成分の分泌態度について相関性 を検討した（表 7)。

$\mathrm{Cl}-$ - $\mathrm{H}+, \mathrm{Cl}-$ - F-HCl, $\mathrm{H}+$ - F-HClは正の相

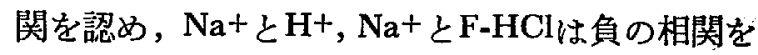
認める. $\mathrm{Cl}-$ とa+は負の相関の傾向を認める が, 推計学的に有意性は認められなかつた。つき にH+, Cl-, F-HCl濃度の増加度扣よびNa+浱度 減少度にかんして, $\mathrm{Na}+$ と $\mathrm{H}+, \mathrm{Cl}-; \mathrm{F}-\mathrm{HCl}$ の関 係についてみぬ場合, $\mathrm{Na}+$ と $\mathrm{F}-\mathrm{HCl}, \mathrm{Na}+$ と $\mathrm{H}+の$ 相関係数の間に有意の差を認めない，一方Cl-に ついても同様㰸討したが, $\mathrm{Cl}-$ と $\mathrm{F}-\mathrm{HCl}, \mathrm{Cl}-$ と $\mathrm{H}+$ の相関係数の間に有意差を認めず，H+につい てはF-HClと最も高い相関を認めた。

C）各疾患における胃液内各成分の相関 Histamine刺激による各成分の動態を疾患別に 


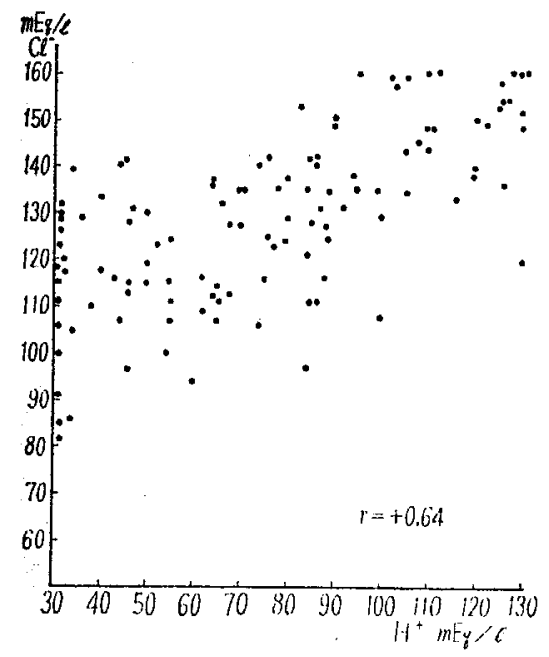

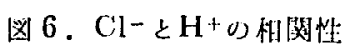

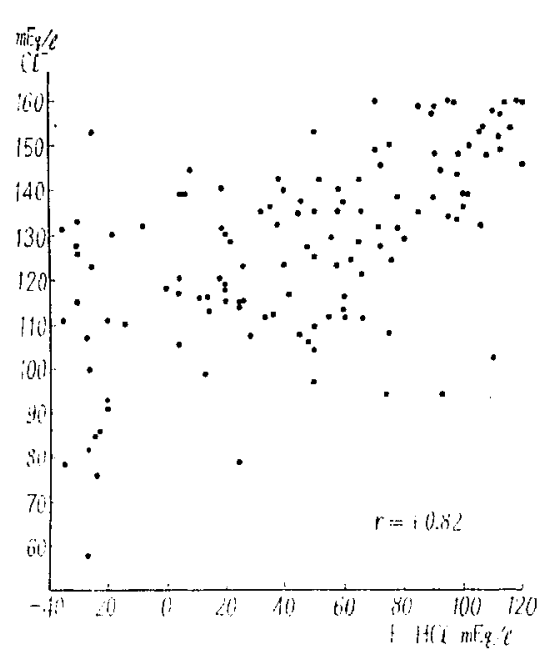

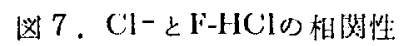

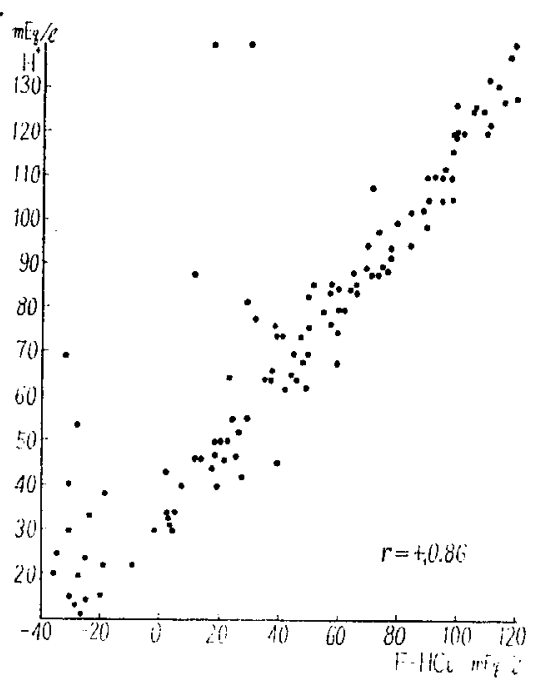

図 8. H+とF-HClの相閣性

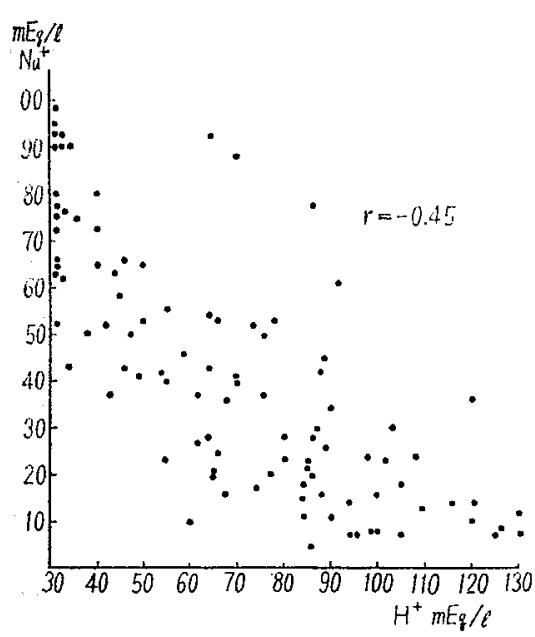

函 $9 \mathrm{H}+$ と $\mathrm{Na}+$ の相関性

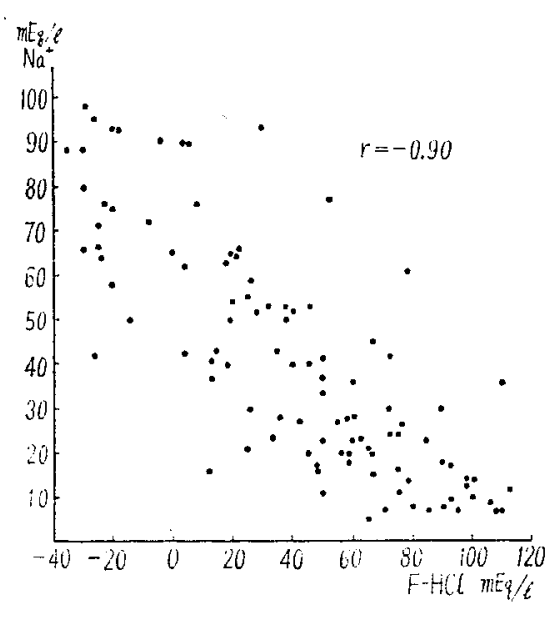

図10. $\mathrm{Na}+$ と F-HClの相関性

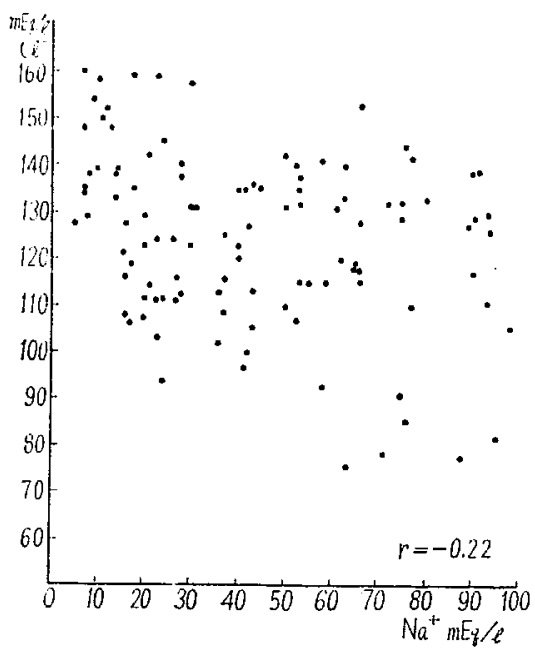

図11. $\mathrm{Cl}$-と $\mathrm{Na}+$ の相関性
表 8. 胃液内各成分の相関性（筷患別）

\begin{tabular}{|c|c|c|c|c|}
\hline & 正 常 & 霄流塞 & 䨚 & 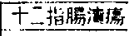 \\
\hline $\mathrm{Cl}^{-}: \mathrm{H}^{+}$ & $+0.63^{\circ}$ & +0.29 & $+0.16^{\circ}$ & $+0.47^{\circ}$ \\
\hline $\mathrm{Cl}: \mathrm{FHCl}$ & $+0.61^{\circ}$ & +0.24 & +0.35 & $+0.42^{6}$ \\
\hline $\mathrm{Cl}^{-}: \mathrm{Na}^{+}$ & -0.36 & -0.06 & -0.37 & -0.45 \\
\hline $\mathrm{Na}^{+}: \mathrm{H}^{+}$ & -0.23 & $-0.59^{\circ}$ & -0.04 & $-0.86^{\circ}$ \\
\hline$N_{a}^{+}: F+H C$ & $-0.65^{\circ}$ & $-0.66^{\circ}$ & $-0.62^{\circ}$ & $-0.87^{\circ}$ \\
\hline $\mathrm{F}-\mathrm{HCl}: \mathrm{H}^{+}$ & $+0.83^{\circ}$ & $+0.79^{\circ}$ & $+0.85^{\circ}$ & $+0.88^{\circ}$ \\
\hline
\end{tabular}

基礎分泌と $\mathrm{Cl}$ 一最高反応時值の变動幅で検討した (表 8 ).

$\mathrm{H}+$ と F-HClは各疾患とも正の相関を認め, $\mathrm{Na}+$ と $\mathrm{F}-\mathrm{HCl}$ も負の相関を認めた。一方 $\mathrm{Cl}$-濃度変動 の比較的低い，胃癌，胃潰湯で $\mathrm{Cl}-$ はH+, F-HCl と相関を認めない。

小括. 胃液内成分の相関を検討した。刺激後の 各成分の分泌動態をみるために $\mathrm{Cl}$-変動幅につい て検討したが, $\mathrm{Cl}-と \mathrm{H}^{+}, \mathrm{Cl}-$ と $\mathrm{F}-\mathrm{HCl}$ の相関係数 


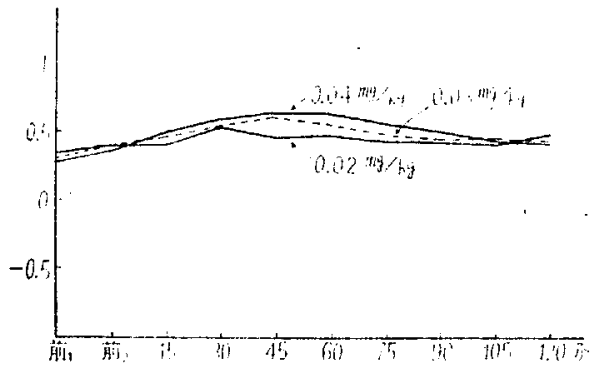

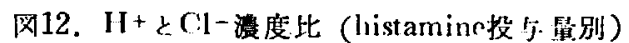

の間に有意美を惢めず, $\mathrm{Na}+と \mathrm{H}+, \mathrm{Na}+$ と $\mathrm{F}-\mathrm{HCl}$ の相関係数の間に有意美を認めない。一方 $\mathrm{Cl}$ 一最 高反沁時における各成分濃度分布の相関をみたが $\mathrm{Cl}$ は $\mathrm{F}-\mathrm{HCl}$ と高い相関を示し, $\mathrm{Na}+も \mathrm{~F}-\mathrm{HCl}$ と高 い負の相関を認めた. F-HCl と $\mathrm{H}+, \mathrm{F}-\mathrm{HCl} と \mathrm{Cl}-$ の相関係数の間に有意差を認めなからた。

疾患別に各成分の相関を検討したが，Cl一变動 幅の比較的低い胃癌, 胃潰瘍では $\mathrm{Cl}-2 \mathrm{H}+, \mathrm{F}-\mathrm{HCl}$ の間に相関は認められなからた。

7） $\mathrm{Cl}-と \mathrm{H}^{+}$濃度比の変動

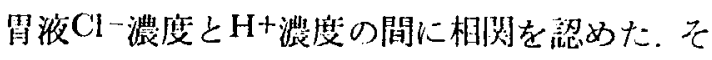

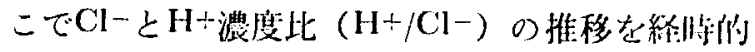
に检討した。

A) Histamine投与㹂に上万变動（网12）

Histamine投与舅別に $\mathrm{H}+/ \mathrm{Cl}$ 一比を検討した。

Histamine $0.02 \mathrm{mg} / \mathrm{kg}$ 投与群では基礎分泌 $0.39 \pm$ 0.14 , 刺激後や>增加 L, 刺激30分後に最高健 $0.53 \pm 0.08$ に達し，以後減少する。 histamine 0.03 $\mathrm{mg} / \mathrm{kg}$ 投与群では, 基礎分泌 $0.39 \pm 0.08$, 最高值は 刺激後 45 分で $0.59 \pm 0.08$ に達する. histamine 0.04

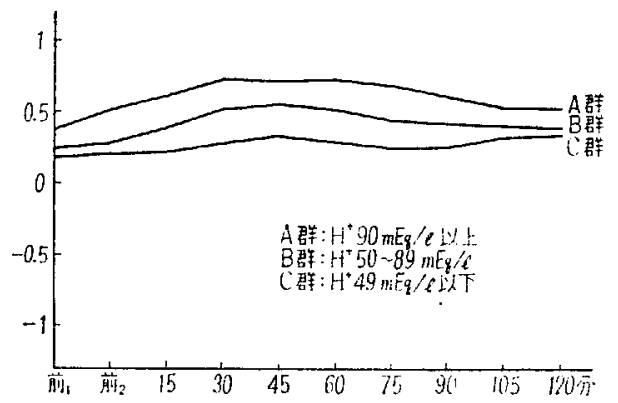

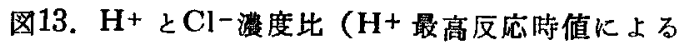
分類)

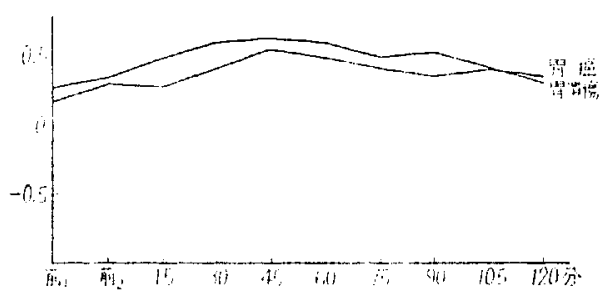

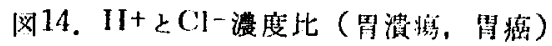

$\mathrm{mg} / \mathrm{kg}$ 投少群では基礎分泌 $0.35 \pm 0.06$, 最高值は 刺激後 45 分で $0.62 \pm 0.06$ 亿達さる。 histamine投 与量別各群においてその基礎分泌之最高值の間を 検定したが，いずれも有意差を言念めず，また各投 与群閂の最高値㧍よび基礎分泌間に有意差を認め ない.

B ） $\mathrm{H}+$ 最高反応時値による分類

$\mathrm{H}^{+}$最高反応時值の分類で $\mathrm{H}+\mathrm{Cl}$ 一比を検討した (図13). $\mathrm{H}^{+}$濃度の高いA群では基礎分泌 $0.52 \pm$ 0.30 , 最高値 $0.73 \pm 0.22$ を示し最もをの比が大 である.H+濃度の低いC群では基礎分泌 $0.21 \pm$ 0.15 , 最高值 $0.33 \pm 0.20$ で 3 群中最子低く, B 群 山基碟分必 $0.28 \pm 0.17$, 最高倠 $0.55 \pm 0.13$ オ 群, B 群の中留を占める。冬群最高值はA群と B 群 $\left(\mathrm{t}_{0.05(102)}=4.98\right)$, B 群と C 群 $\left(\mathrm{t}_{\mathbf{0}, 05(71)}=5.72\right)$ ○間に有意差を澹める。

C）胃潰瘍，胃癌における変動（図14）

胃潰瘍, 胃癖について $\mathrm{H}+\mathrm{Cl}-$ 比を娭討した。 胃癌では基礎分泌 $0.30 \pm 0.17$, 最高値 $0.55 \pm 0.14$ は刺激後45分で基礎分泌に比べ增加を認める $\left(\mathrm{t}_{0.05(20)}=3.72\right)$. 胃潰痬では基礎分泌 $0.34 \pm 0.47$, 最高値 $0.63 \pm 0.67$ は刺激 45 分後に達し, 基礎分泌 との間に有意の差を譛めない $\left(\mathbf{t}_{0.05(56)}=1.68\right)$. ま た両疾患の基礎分泌値 $\left(\mathrm{t}_{0.05(36)}=0.45\right)$, 最高值

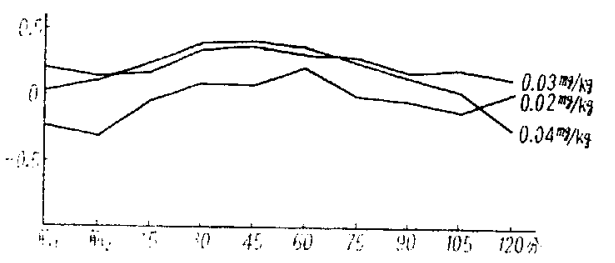

图15． $\mathrm{F}-\mathrm{HCl}$ と $\mathrm{Cl}$-濃度比（histamine投与量别) 


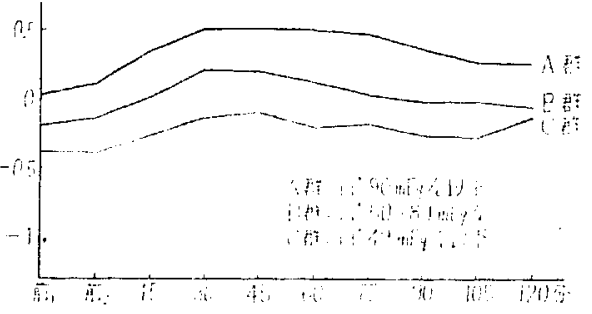

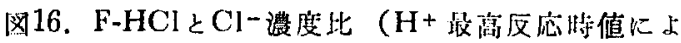
る分類）

$\left(\mathrm{t}_{0.05(40)}=1.17 ）\right.$ の間に有意差を認めない。

8） $\mathrm{Cl}-$ - F-HCl濃度比の変動

胃液 $\mathrm{Cl}$-濃度と $\mathrm{F}-\mathrm{HCl}$ 濃度比 $(\mathrm{F}-\mathrm{HCl} / \mathrm{Cl}-)$ の推 移を $\mathrm{H}+/ \mathrm{Cl}-$ 比同様に検討した。

A) Histamine投与量による変動（四15）

Histamine $0.02 \mathrm{mg} / \mathrm{kg}$ 投与例胃液 $\mathrm{F}-\mathrm{HCl} / \mathrm{Cl}$ - 比は 基礎分泌 $-0.33 \pm 0.52$ ，最高值 $0.18 \pm 0.41$ 法刺 激後60分に認め，基礎分泌比へ堌加を認める $\left(\mathrm{t}_{0.05(67)}=2.71\right)$.

Histamine $0.03 \mathrm{mg} / \mathrm{kg}$ 投与例では基璴分泌 $0.06 \pm$ 0.33 , 最高值 $0.37 \pm 0.30$ は刺激 45 分後に億め, 基礎分泌に比べ增加を示した（ $\left.\mathrm{t}_{0.05(86)}=5.61\right)$. histamine $0.04 \mathrm{mg} / \mathrm{kg}$ 投与例では基礎分泌 $0.07 \pm$ 0.33 , 最高值 $0.34 \pm 0.35$ は刺激 45 分後に認め，基 礎分泌に比べ增加を示した $\left(\mathrm{t}_{0.05(98)}=9.01\right)$.

各群最高値間を推部学的に検討した。 histamine $0.02 \mathrm{mg} / \mathrm{kg}<0.03 \mathrm{mg} / \mathrm{kg} \quad\left(\mathrm{t}_{0.05(82)}=2.71\right)$. histamine $0.02 \mathrm{mg} / \mathrm{kg}$ と $0.04 \mathrm{Mg} / \mathrm{kg}\left(\mathrm{t}_{\mathbf{0 . 0 5 ( 8 6 )}}=2.91\right)$ の間に有 意差が認められ, histamine $0.03 \mathrm{mg} / \mathrm{kg}$ と $0.04 \mathrm{IIg} / \mathrm{kg}$ $\left(\mathrm{t}_{0.05(98)}=0.42\right)$ の間に有意差を認めない.

B ） $\mathrm{H}+$ 最高反応値に上る分類（図16）

$\mathrm{H}+$ 最高反応值分類にしたがって $\mathrm{F}-\mathrm{HCl} / \mathrm{Cl}-$ 比 を検討した．H+濃度の高いA群ではF-HCl/Cl比は基礎分泌 $0.11 \pm 0.45$, 最高值 $0.51 \pm 0.41$ 江基

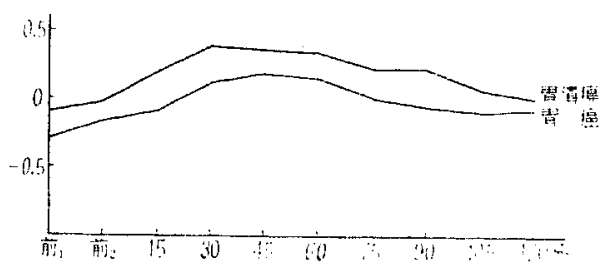

図17. $\mathrm{F}-\mathrm{HCl}$ とCl-㴚度比（胃潰瘍，胃将）
礎分泌に比べ増加を認める $\left(\mathrm{t}_{0.05(108)}=5.21\right) . \mathrm{H}+$ 濃度の低いC群では基碟分泌 $-0.39 \pm 0.54$, 最高 阭(0.21土0.34は基礎分泌值に比べ增加を器的た $\left(\mathrm{t}_{0.05(48)}=2.63\right)$. B 群虫基碟分泌 $-0.13 \pm 0.31$, 最

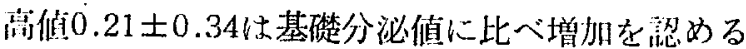
$\left(\mathrm{t}_{\mathbf{0} 05(96)}=5.01\right)$. 各群最高值間を検分したところ $\mathrm{A}$ 群亡 B 群 $\left(\mathrm{t}_{0.05(107)}=4.62\right), \mathrm{B}$ 群之 $\mathrm{C}$ 群 $\left(\mathrm{t}_{0.05(77}\right.$, $=7.57 ）$ の間に有意差を認めた。

C）胃潰瘍，胃癌に拈ける変動（図17）

胃癌では基礎分泌 $-0.17 \pm 0.24$ ，最高值0.19士 0.31 は基礎分泌に比べ增加を認めた（ $\mathrm{t}_{005(20)}=$ 3.06).

胃潰瘍では基礎分泌一 $-0.03 \pm 0.96$, 最高値0.39 \pm 0.88 は基礎分泌に比べ增加を涩めた（ $\mathrm{t}_{0 \text { 05(56) }}=$ $6.03)$.

阿疾患の基礎分泌值 $\left(\mathrm{t}_{005(36)}=1.47\right)$ 間に有意 差を認めず, 最高值 $\left(t_{005(42)}=2.02 ）\right.$ で有意差を 諗めた。

小括. $\mathrm{H}+/ \mathrm{Cl}$-此はhistamine刺激後も変動は少 なく, F-HCl/Cl一比はhistamine刺激後增加を認め た。一方 $\mathrm{H}+/ \mathrm{Cl}-$ 比, $\mathrm{F}-\mathrm{HCl} / \mathrm{Cl}-$ 比とも $\mathrm{H}+$ 濃度の 高いものではその比も高く, H+濃度の低いもの ではその比も低い傾向を認めた. histamine投与量 別ではhistamine $0.02 \mathrm{mg} / \mathrm{kg}$ と histamine $0.03 \mathrm{mg} / \mathrm{kg}$, $0.04 \mathrm{mg} / \mathrm{kg}$ の間に $\mathrm{F}-\mathrm{HCl} / \mathrm{Cl}$ 一此で有意差を認め, $\mathrm{H}+/ \mathrm{Cl}$ 一比で差を認めない，胃溃瘍と羿癌の間で は最高值で $\mathrm{F}-\mathrm{HCl} / \mathrm{Cl}$-比に有意差を認め, $\mathrm{H}+/ \mathrm{Cl}$ 比で差を認めない，すなわち $\mathrm{H}+/ \mathrm{Cl}$-比が注ぼ constantであるのに対し，F- $\mathrm{HCl} / \mathrm{Cl}$-比の変動を 認めたことはF-HClが他のアルカリ金属の影響を 受ける結果と考觉る。

\section{9）胃液 $\mathrm{Cl}$-絶対量}

胃液 $\mathrm{Cl}$-濃度について検討して来たが，胃腺細 胞の分泌機能を考える上で忘れてならないものに 水分泌がある。すなわち水分泌量に上り，各濃度 は変動し，したがつて絶対量について検討する必 要がある。胃液量は基礎分泌值 $16.4 \pm 3.6 \mathrm{ml}$, Cl一濃度最高反応時で $24.2 \pm 3.6 \mathrm{ml}$ と增加を示 す。しかし胃液採取にかんしては，被検者の胃の 


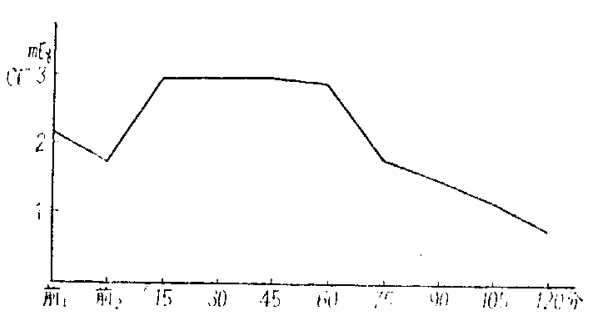

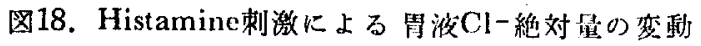

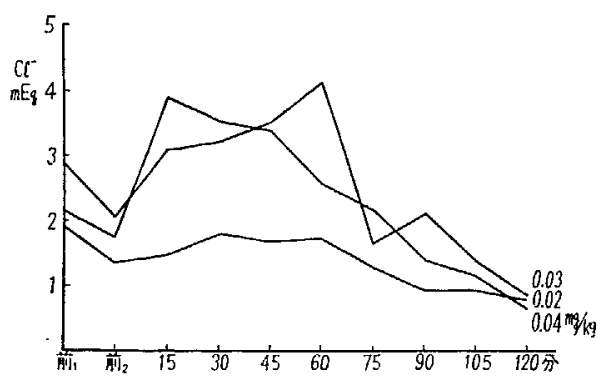

图19，胃液 $\mathrm{Cl}$ 一維刘骨の变動 (Histamine投与鼠别)

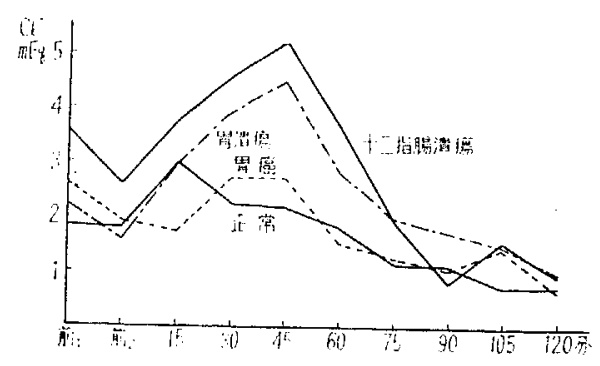

図20. $\mathrm{Cl}$-絶対量疾㭧別変動

位置, 形態, tonus, 胃粘膜の状態に問題があり， また，あらゆる手段を講じたが，採取法自体が盲 目的行為であるため，採取した胃液量を絶対的な ものと信じ難く，したがつて本研究では $\mathrm{Cl}$-絶刘 量にかんして量的攧向を検討するに止めた。

A) Histamine投与による胃液 $\mathrm{Cl}$-量の変動(図 18)

Histamine投与により 胃液 $\mathrm{Cl}$ 一量は增加し, 刺激 60分間はほ ジ同量の分泌様相を呈し，以後急激に 減少を示した。

B) Histamine投与量による変動（図19）

Histamine $0.02 \mathrm{mg} / \mathrm{kg}$ 投与群では刺激後 $\mathrm{Cl}$ 一量の 変動は少なく, histamine $0.03 \mathrm{mg} / \mathrm{kg}, 0.04 \mathrm{~kg} / \mathrm{mg}$ 投与 群では刺激後增加し, histamine $0.03 \mathrm{mg} / \mathrm{kg}$ 投与群

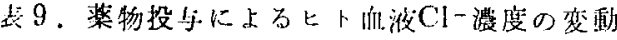
(单位 $\mathrm{mEq} / l$ )

\begin{tabular}{|c|c|c|c|c|}
\hline & \multicolumn{2}{|c|}{ 血第C } & \multicolumn{2}{|c|}{ 全侐 C } \\
\hline & 䒩扬投与群 & 対 照 & 菜物投与群 & 刘 照 \\
\hline $\begin{array}{l}\text { Actedadonide } \\
500 \mathrm{my}\end{array}$ & $106.0 \pm 13.0$ & $104.8 \pm 6.7$ & $75.4 \pm 3.5$ & $78.2 \pm 5.2$ \\
\hline $\begin{array}{l}\text { Aretuzidumide } \\
1000 \mathrm{mg}\end{array}$ & $103.6 \pm 1.4^{\circ}$ & $101.9 \pm 2.7$ & $81.4 \pm 3.4^{\circ}$ & $76.1 \pm 2.0$ \\
\hline Spironolatatone & $102.1 \pm 3.9$ & $100.3 \pm 7.1$ & $74.1 \pm 8.6$ & $67.9 \pm 8.2$ \\
\hline Chicrthalidone & $104.3 \pm 5.0$ & $109.6 \pm 4.0$ & $79.6 \pm 6.2^{\circ}$ & $85.9 \pm 3.0$ \\
\hline Prednisolone & $97.5 \pm 2.0$ & $103.5 \pm 6.8$ & $83.7 \pm 3.0$ & $83.9 \pm 8.8$ \\
\hline 鈢銀刑展菜 & $97.3 \pm 4.2^{\circ}$ & $100.1 \pm 2.5$ & $82.6 \pm 7.8^{\circ}$ & $83.0 \pm 4.2$ \\
\hline
\end{tabular}

では刺激後60分に, histamine $0.04 \mathrm{mg} / \mathrm{kg}$ 投与群で は刺激後15分に最高值を㢹めた。

C）疾患別䎡液 $\mathrm{Cl}$-維刘量の変動（図20）

胃液 $\mathrm{Cl}$ 一量を各疾患について検討した。十二指 腸潰瘍, 胃潰瘍では刺激後急激に增加し，45分後 に最高值に達し以後減少する。胃癌, 正常例では 刺激後に潰瘍例に比べ変動少なく, 胃癌では刺激 後15分に, 正常では30分後に最高值に達した。

小括. 胃液 $\mathrm{Cl}$ - 量は $\mathrm{Cl}$-濃度とほメ゙一致した变 動を示した，疾患別では潰痬例では水分泌が多く 変動が大である傾向を認放た。

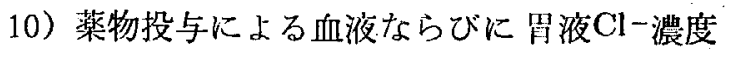
の変動

体液電解質代謝に影響を及ぼすと考えられる各 種薬物を投与し，血液ならびに 胃液 $\mathrm{Cl}$ 一濃度につ いて検討した。

\section{A) 臨床例 (婊 9,10$)$}

a) acetazolamide $500 \mathrm{mg}$

血液ならびに胃液 $\mathrm{Cl}$-濃度は対照に比べ有意の 変動を示さない。

b) acetazolamide $1000 \mathrm{mg}$

血桨 $\left(t_{0.05(14)}=3.46\right)$, 全血 $\left(t_{0.05(14)}=8.41\right)$ と も対照に比へ增加し, 胃液 $\mathrm{Cl}$-濃度は平均值で減 


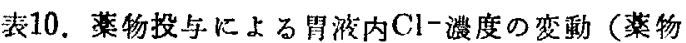
投 $j$. 例一刘照例）（位位 $\mathrm{mEq} / l$ )

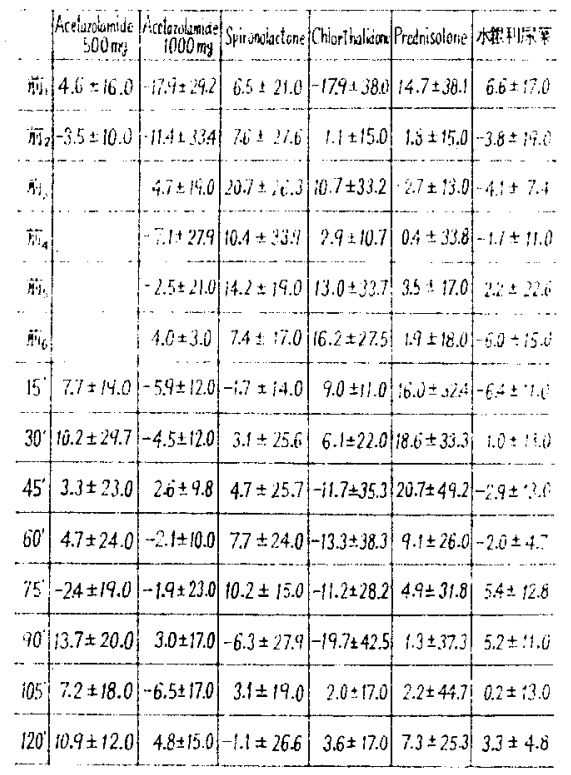

装11。イヌ血液ならびに胃淮 $\mathrm{Cl}$ 一濃度の变動 (

\begin{tabular}{|c|c|c|c|}
\hline & 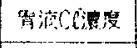 & 血浆 $\mathrm{Cl}$ 浱度 & 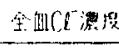 \\
\hline 萠, & $133.3 \pm 32.2$ & & \\
\hline 前 & $142.1 \pm 26.2$ & $114.5+8.5$ & $85.9 \pm 8.1$ \\
\hline $15^{\prime}$ & $151.0 \pm 23.0$ & $113.6 \pm 5.2$ & $84.3 \pm 8.1$ \\
\hline $30^{\prime}$ & $162.6 \pm 16.0$ & & \\
\hline $45^{\prime}$ & $164.2 \pm 17.0$ & $110.9 \pm 2.7$ & $86.3 \pm 7.3$ \\
\hline $60^{\prime}$ & $167.1 \pm 17.0$ & & \\
\hline $75^{\prime}$ & $164.1 \pm 15.0$ & $114.1 \pm 3.9$ & $84.6 \pm 5.8$ \\
\hline $90^{\prime}$ & $155.4 \pm 16.0$ & & \\
\hline
\end{tabular}

少の攧を示したが，推計学的に有意差を認めな W.

c) spironolactone

血液, 胃液 $\mathrm{Cl}$-濃度は平圴值で增加の傾向を示 すが，推計学的に有意差を認めない。

d) chlorthalidone
洨12。イヌ血液Cl一濃度の薬物に上る影響 (

\begin{tabular}{|c|c|c|c|c|}
\hline & \multicolumn{2}{|c|}{ 血摽 $\mathrm{C}^{-}$} & \multicolumn{2}{|c|}{ 全 而C $C^{-}$} \\
\hline & 赖清前 & 整傮 150 & 利整前 & 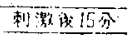 \\
\hline 对照 & $114.5 \pm 8.5$ & $113.6 \pm 5 ?$ & $85.9 \pm 8.1$ & $84.3 \pm 8.1$ \\
\hline Aztiaristaridit & $106.5 \pm 5.0$ & $105.2 \pm 5.5$ & $78.5 \pm+1$ & $80.9 \pm 6.4$ \\
\hline Oulluin & $100.4 \pm 10.0$ & $10 n .8 \pm 11.0$ & $89.5+11.0$ & $872+13.0$ \\
\hline Pridiviolatin & $105.2 \pm 5.6^{\circ}$ & $104.4 \pm 5.5$ & $87.0 \pm 6.8$ & $87.1+4.1$ \\
\hline 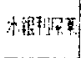 & $97.4+5.4$ & $90.0 \pm 0$ & $81.9+4.7$ & $78.7 \pm 5.3$ \\
\hline
\end{tabular}
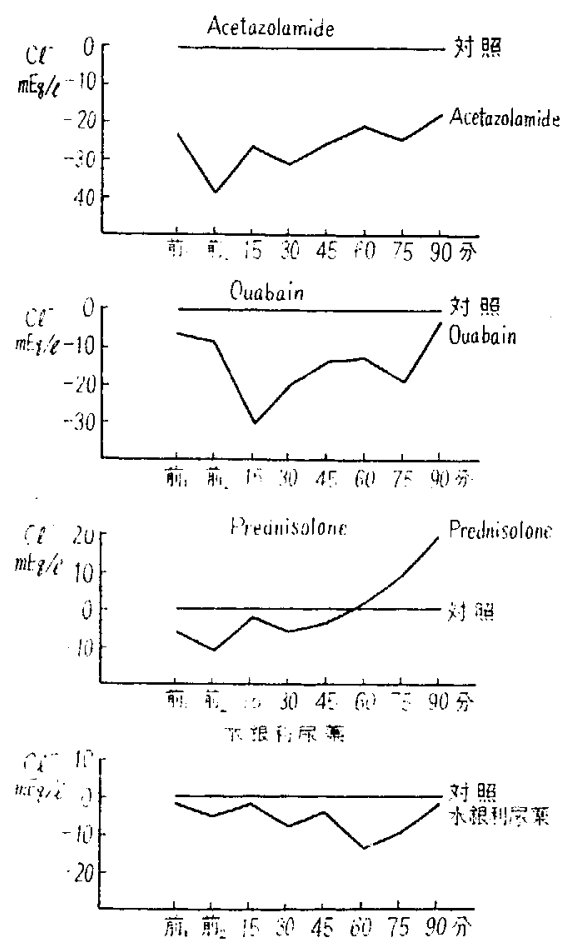

図21，薬物投与による胃液 $\mathrm{Cl}$ 一涰度の变動（イヌ）

血浆 $\mathrm{Cl}$-濃度 $\left(\mathrm{t}_{0.05(12)}=-6.16\right)$ は減少 , 全 血ならびに胃液 $\mathrm{Cl}$ 一濃度は平圴值で減少の傾向を 認めたが，推計学的に有意差を認めない。

e) prednisolone

胃液Cl-濃度はhistamine刺激後增加の傾向を

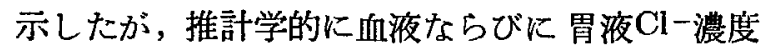
に有意差を認めない。

f）水銀利尿薬 
羿液 $\mathrm{Cl}$ 一濃度に有意差を認めず，洫将 $\mathrm{Cl}$ 一濃度 汢減少した $\left(\mathrm{t}_{0.05(10)}=-3.63\right)$.

B）動物实験例

i) 対照（表11）

各種薬物の胃液ならびに血液 $\mathrm{Cl}$ 一濃度への影 響をみるために 5 15kg の成大に 亿istamine 0.1 $\mathrm{mg} / \mathrm{kg}$ を投与し，経時的に胃液ならびに血液 $\mathrm{Cl}$ 一濃 度を検討した。イヌ胃液 $\mathrm{Cl}$ 一濃度はhistamme刺激 で急激に增加し，刺激45分後に最高値に達する。 血液 $\mathrm{Cl}$-濃度は血将，全血ともhistamine刺激前な らびに刺激15分後, 45分後, 75分後で有意差を認 めない,

ii）薬物投与による血夜ならびに胃液 $\mathrm{Cl}$ 一濃度 の変動（表12，図21）

a) acetazolamide

血液 $\mathrm{CI}$-濃度は基礎分泌時全血で減少し（ $\mathrm{t}_{0.05}$ $\left.\mathrm{t}_{(15)}=-2.26\right)$, 血浆では有意の变動を示さなかつ た，胃液Cl一濃度を対照群との差で示すと図20の 如くで, 著明な $\mathrm{Cl}$ 一濃度の減少を認めた。すなわり 基礎分泌值 $104.8 \pm 39.9 \mathrm{mEq} / l$ (対照142.1 126.2 $\mathrm{mEq} / l), \mathrm{t}_{0.05(15)}=-9.65$, 刺激後 45 分で対照之の 差が最も著明で $132.6 \pm 27.1 \mathrm{mEq} / l$ (対照 162.6 $\pm 16.0 \mathrm{mEq} / l), \mathrm{t}_{0.05(15)}=-26.93$ 示した。

b) ouabain

血液 $\mathrm{Cl}$-濃度に有意差を認めない，罠液 $\mathrm{Cl}$ 一濃 度はhistamine刺激後著明な減少灻示す。基礎 分泌值 $133.7 \pm 27.8 \mathrm{mEq} / l$ (対照 $142.1 \mathrm{mEq} / l$ ) $605(13)=-5.30$, 刺激後 15 分で対照との差が最 も著明で $120.8 \pm 6.5 \mathrm{mEq} / l$ (刘照 $150.1 \pm 23.0$ $\mathrm{mEq} / l), \mathrm{t}_{0.05(15)}=-4.29$ を示した。

c) prednisolone

血浆 $\mathrm{Cl}$-濃度はhistamine刺激前後とも対照に比 へ減少を示した，胃液 $\mathrm{Cl}$ 一濃度は基礎分泌は131.3 $\pm 29.4 \mathrm{mEq} / l$ (対照 $142.1 \pm 26.2 \mathrm{mEq} / l$ ) $\mathrm{t}_{0.05(18)}=$ -6.31で減少し, histamine刺激75分後より增加 の傾向を認めたが, 刺激後75分, 90 分の例数不足 のため有意娭定より除外した。

d) 水銀利尿薬

血浆 $\mathrm{Cl}$-濃度はhistamine刺激前後とも減少し
た。一方全血Cl一濃度には有意差を認めない。 胃液 $\mathrm{Cl}$-濃度は基礎分泌 $138.0 \pm 19.0 \mathrm{mEq} / l$ （対 照 $142.1 \pm 26.2 \mathrm{mEq} / l) \mathrm{t}_{0.05(12)}=-2.51$, 刺激後 60 分で $156.8 \pm 3.9 \mathrm{mEq} / l$ （刘照 $167.1 \pm 17.0 \mathrm{~m}$ $\mathrm{Eq} / l) \mathrm{t}_{0.05(12)}=-13.48$ ととを減少を示した.

小括. Acetazolamide: acetazolamide $500 \mathrm{mg}$ 投 与例では鼠液, 血液 $\mathrm{Cl}$-湍度に变動を認めず, 1000 mg投与例でも胃液で減少の傾向㴓めるが有意差 はなく，血液では增州を認める。動物例では全血 ならびに胃液 $\mathrm{Cl}$ 一濃度の減少を諗めた。

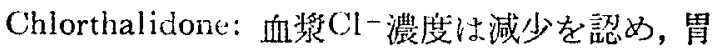

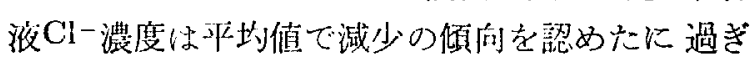
ない.

水銀利水蒋：臨林例, 動物例已も血浆 $\mathrm{Cl}$-濃

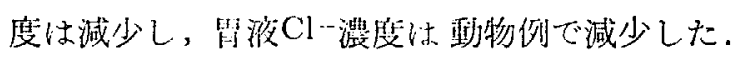

Prednisolone: 動物例で血浆 $\mathrm{Cl}$ - 濃度は減少 し，胃液 $\mathrm{Cl}$ 一濃度は刺激後培加の值何を認める。

Spironlactone：血沙, 珰液 $\mathrm{Cl}$-濃度に变動を認 ぬない.

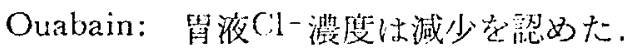

\section{IV. 結括ならびに考案}

総Cl一瀑度を中心K血被尔上び型液内電解質を 测定しhistamine刺激羭後の電解䨘の推移につい て述ベた。

胃液成分は主として壁細胞方.万分泌されると推

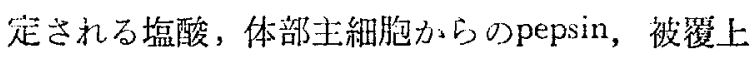
皮細胞, 腺頝部主細胞からの粼液等で方る。胃液 はこれら腺分泌機能の総和であり, 胃腺細胞の器 質的および機能的障等の結果生じた胃分泌機能の 翼常を知る上に重要である。

本実駼では $\mathrm{Cl}$-のhistamine刺激前後の血液およ び胃液内における推移を追究し, 雸壁の状態によ りどのよらに変動し，また他の胃液内成分とどの ような関係を示すか娭討した。

血液Cl一濃度はhistanine测激15分後で全血, 血

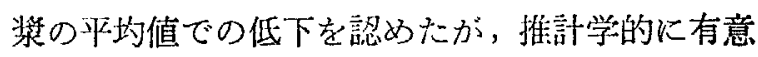
差は認めず，変動は少ない上らである。また血液 と胃液 $\mathrm{Cl}$ 一濃度の関係を基整分泌について 娭討し たが, 胃液 $\mathrm{Cl}$ 一濃度は血液 $\mathrm{Cl}$-浱度の変動と有意の 
関係を認めなかつた。

胃液 $\mathrm{Cl}$ 一濃度はhistamine刺激に上り增加し，刺 激後45分で最高值に達し，以後漸減の傾向を示し た. histamine投与量を变えてみたが胃液 $\mathrm{Cl}$ 一濃度 はhistamine投与量が增すにしたがい，その变動 も大となつたが, histamine $0.03 \mathrm{mg} / \mathrm{kg} と 0.04 \mathrm{mg} / \mathrm{kg}$ 投与群の間に有意差を認めない。 Kay ヒスタミンについて0.01 0.12mg/kg まで投与 量を変えて投与し， $0.04 \mathrm{mg} / \mathrm{kg}$ がmaximal acid outputの最小刺激量であることを報告し，日本人 についても, 大井 ${ }^{8}$, 忠 $\uplus^{6)}$, 和㘴らがhistamine 0.04 0.05mg/kgを極大值と認めて拄り, $\mathrm{Cl}$ 一濃度 にかんしては はistamine $0.03 \sim 0.04 \mathrm{mg} / \mathrm{kg} か ゙$ 極大值 と思われる。そこでhistamine $0.03 \mathrm{mg} / \mathrm{kg}, 0.04$ $\mathrm{mg} / \mathrm{kg}$ 投与例を主体にして検討を行なつた。

Histamine刺激前後の畾液 $\mathrm{Cl}$-濃度の関䋆を娭 討するために，基礎分泌 $\mathrm{Cl}$ 一濃度により 3 群に分 け検討したところ，基整分泌 $\mathrm{Cl}$-濃度の高いもの は刺激後 $\mathrm{Cl}$ 一濃度も菏了，基礎分泌值の低いもの は刺激後も低い傾向を讃めた。また刺激後 $\mathrm{Cl}$ 一濃 度最高反応時值により 3 群に分けてみても，CI最高反応時值の高いものでは基礎分泌値も高く, その変動も大であり，最高反応值の低いものは基 礎分泌值，変動幅ともに低い傾问を認好る。この ことは腺細胞の分泌能の高いものでは, 刺激前上 りすでに分泌能の低いものより $\mathrm{Cl}-$ 分泌が多いこ とを示唆しているものと思われ, Lambling ${ }^{7} の$ 分 画 Bが胃粘膜の感受性を表現しているといら報告 がCl一についても同意できるものと考える.

一方H+濃度によつて 3 群に分けて检討した場 合でも, $\mathrm{H}+$ 濃度の高いものではCl一濃度は常に高 く, $\mathrm{H}^{+}$濃度の低いものではCl-濃度も低い傾向を 認めたので, 従来いわれていた $\mathrm{H}+$ 濃度之各種疾 患との関係を $\mathrm{Cl}$-濃度についても検討した。基碟 分泌 $\mathrm{Cl}^{-}$濃度は各種疾患間に有意差を認めず, 刺 激後 $\mathrm{Cl}$-濃度最高反応值では, 十二指腸潰演が最 も高く, ついで正常, 胃潰瘍, 帠癌の順で低下し， 胃癌と各種疾患の間に有意差を認めた。 Hirschowitz $^{9}$ は胃癌と胃潰瘍の鑑別龍断として $\mathrm{H}+80$
$\mathrm{mEq} / l, \mathrm{Cl}-135 \mathrm{mEq} / l$ を境に 良性と悪性に分けて いるが，本実験でも型癌例では $140 \mathrm{mEq} / l$ 艺越す ものは恝められなかつたが，罪瀆富例ではその分

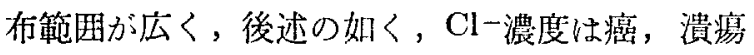
等の病紧の影響は二次的には受けてもあくまで腺 細胞の分泌能力に依存すると考克られるので， Hirchowitz ${ }^{9}$ の上うな所見は得がたいものと考え る。

大井 ${ }^{8)}$ は各種疾患の照壁細胞の分布密度を調べ

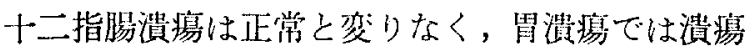
を焦点とした分布密度の減少を䛱め, 罚癌でも随 瘍を中心に壁細胞の減少を惩め, その減少度は, 胃 癌, 胃潰瘍とも, その随伴性胃炎の広さ扣上び程度 に比例すると報告しており，晹川もまたhistamine $0.02 \mathrm{mg} / \mathrm{kg}$ 投与無酸潰䁑例で胃カメラ上怪度ある いは中等度菱維性琴炎荧認めた。本実験でもX線 あるい恃胃カメラで明らかに良性湍㾥之認めら れる胃潰瘍例について，以視鏡的随伴性胃炎像 を，表在性胃炎，菱縮性胃炎軽度，菱縮性琴炎高

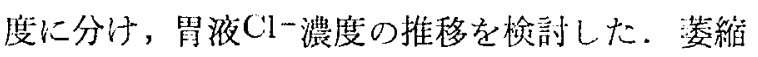
性胃炎高度のものでは基礎分泌值, 最商反応値, $\mathrm{Cl}$-変動幅とも低く，表在性胃炎を呈するもので は高い傾向を諗めた。この事より腷液 $\mathrm{Cl}$ 一濃度は 病学自体の影響は二次的には受けるにしても，䝿 粘膜の様相，すなわち壁細胞個々の状態ならびに 分布状態によつて左右さ机るものと推察する.

$\mathrm{Cl}$-は胃液中で大部分 $\mathrm{HCl} の$ 形で存在するが， その外にNa+, $\mathrm{K}+, \mathrm{MgH}, \mathrm{Ca}$ 等結合しているも のもある。.そこでこれら各成分が胃夜内でどのよ らな変動を示すかを， $\mathrm{Cl}$ 一最高反応時值ならびに Cl一変動幅について検討した。

$\mathrm{Cl}$-㰩動幅における各成分はF-HClが最も变動 激しく,ついでH+, $\mathrm{Cl}$-の順に低下し, $\mathrm{Na}^{+}$は刺激 後減少した。そこでこれら各成分の分泌態度を相 関係数で検討したところ, $\mathrm{Cl}$ 一 $\mathrm{H}+\mathrm{Cl}-$ - $\mathrm{F}-\mathrm{HCl}$ の相関係数の間に有意差を認めず， $\mathrm{Na}+\llcorner\mathrm{H}+$, $\mathrm{Na}+と \mathrm{~F}-\mathrm{HCl}$ の相関係数の間にも差を認めない。 一方 $\mathrm{H}+$ は $\mathrm{F}-\mathrm{HCl}$ 之高い相関性を琶めた。 $\mathrm{Cl}$ 一最 高反応時における各成分の分布状態を相関係数で 
検討したところ， $\mathrm{Na}$ おょびCl一はF-HClと最も 高い相関を認め, $\mathrm{Cl}$-と $\mathrm{Na}$ に相関は認めず， $\mathrm{H}+$ はF-HClと高い相関を認めた。一方, $\mathrm{F}-\mathrm{HCl} と \mathrm{H}+$, $\mathrm{F}-\mathrm{HCl}$ と Cl-の 各相関係数の間に有意差を認めな かつた，疾患別に各相関係数を検討したが， $\mathrm{Cl}$ 濃度変動の比較的低い胃癌, 胃溃瘍では $\mathrm{Cl}-$ 一他 の成分の間に相関を認めず， $\mathrm{Na}+$ と $\mathrm{F}-\mathrm{HCl}, \mathrm{H}+$ と $\mathrm{F}-\mathrm{HCl}$ は全疾患に相関性を認めた。このことから 胃液内に扣いて $\mathrm{Cl}$ 一と $\mathrm{Na}$ はH+ならびにF-HCl に影響を及ぼし，とくにNa+消長が-HClと高い 負の相関を認めたことは, Hollander ${ }^{10)}$, 和田らに 上る棇 $\mathrm{Cl}-は \mathrm{HCl}$ と，中性 $\mathrm{Cl}-は \mathrm{Na}+$ 一致した変 動を認めた知見と考兄合わせ， F-HClの低い状態 では胃液中に $\mathrm{NaCl}$ が增加するものと考えられる。

胃液内でCl一はH+ならびに $\mathrm{F}-\mathrm{HCl}$ と相関を認め たので,これら各成分濃度比を検討した. $\mathrm{H}+/ \mathrm{Cl}-$ 比は $\mathrm{F}-\mathrm{HCl} / \mathrm{Cl}-$ 比に比べ比較的変動が少なく, histamine刺激前後で有意の変動を示さないのに 反し, $\mathrm{F}-\mathrm{HCl} / \mathrm{Cl}$-比ではhistamine刺激後增加を 示し, $\mathrm{Cl}$-濃度変動の比較的低い histamine 0.02 $\mathrm{mg} / \mathrm{kg}$ 投与群ではその比も低く，胃癌においても低 值を示したことは，F-HClの変動にClーだけでな く Na+等が関与しているためと考学られる。

胃液 $\mathrm{Cl}$-箼度を中心乙して, 胃液内各成分につ いて述べて来たが,これら溶質分泌とともに，溶媒

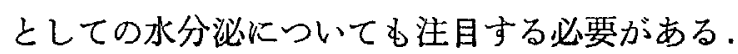
histamine刺激後胃液量は增加し，したがつて胃 液内各成分は稀釈される，そこで胃液内成分の消 長を論ずる場合には絶対量が必要になつて来る. しかし如何なる手段を講しても胃液採取法が盲目 的である限り，埰取胃液量を分泌総量と信じられ ないため, 本研究ではCl-絶対量について単に傾 向について述べた. histamine刺激後 $\mathrm{Cl}$ 一量は增加 し, 刺激後60分間は注ぶ一定量の分泌傾向が認め られた。

Histamine 投与量別に検討したが， histamine $0.02 \mathrm{mg} / \mathrm{kg}$ 投与群で $\mathrm{Cl}$-量の変動は低く, histamine $0.03 \mathrm{mg} / \mathrm{kg}, 0.04 \mathrm{mg} / \mathrm{kg}$ 投与群ではほぐ同 様の変動を示した. 疾患別では潰瘍例の変動が著
明で胃癌では低い傾向を示した。

Cl一の胃への分泌機序については，C A の働き により代謝性 $\mathrm{CO}_{2} か \mathrm{H}_{2} \mathrm{CO}_{3}$ になり，その $\mathrm{H}_{2} \mathrm{CO}_{3}$ の $\mathrm{H}+$ がcarrier 結合し, 代謝エネルギーに上つて分 泌膜面に運ばれるとするH+分泌 のmechanismに つれCl-がpassiveに分泌されるというHollander $^{10)}$, Conway ${ }^{11)}$, Davies $^{12)}, N_{i e l s e n}{ }^{13)}$ らの陧え る passive transport説, またCl一は胃粘膜が酸分 泌を行なつていない時でも胃粘膜への取り込み が行なわれていること，また実際に負の電荷 を有するCl一が，負の䉓位の粘膜面に運ばれる ことはpassive transport説で考学られない面より Cl-active transport説を唱觉る学者むある。

Conway ${ }^{11}$ は $\mathrm{H}+$ の粘膜面への輸送に要する energy源は呼吸系の細胞内酸化還元反応に上り得 られるとするredox theoryを明らかにしまたDavies $^{12}$ はH十+は浆膜側近くでFeH/FeHtの関与により $\mathrm{H}_{2} \mathrm{O}$ より $\mathrm{H}+$ が生成され，これがcarrierにより $\mathrm{H}_{2} \mathrm{O}$ の形で翰送され，分泌小節管において再びH+と なり $\mathrm{Cl}$ とともに分泌される. 分泌小節管内のエ レクトロンはドを介して浆膜側に運ばれるとす るelectron cycle説, ならびにNielsen, Rosenbe$\mathrm{rg}^{13}$ らのH+分泌に高エネルギー燐酸化合物が直 接関与しているとする有機燐酸説等は，いずれ もCl-はpassiveに輸送されるとする説である。 Obrink ${ }^{14)}$ は浆膜側の $\mathrm{Cl}$ 一をBr一に固換し, 粘膜側 へのHBrの分泌様相を検討し，Brに親和珄の強い carrierの存在を推定し, Hogben ${ }^{83153}$ は Cl一の浆膜 面より粘膜面へのfluxがそこの対方向のfluxょり 大であり，またCl一fluxは胃粘膜の電気伝導度よ り計算した值より常に大であることから， $\mathrm{Cl}$-の 移動を容易ならしむなんらかのcarrierの存在を示 唆した。 Rehm ${ }^{16)}$ もまた膜電位によりH+ならび にCl-のfluxが変ることからCl-active transport 説を唱充た。 Cooperstein ${ }^{4)}$ はCl-transportk三つ の異なつたsystem，すなわち，1） active transport, 2) exchange diffusion, 3) passive diffusionがあり，1）と2)にcarrierが関与し, その阻 害薬としてstrophanthidinを挙け゚ている．以上の 
如く胃液分泌機序にかんする説は多㞳にわたり未 解決の点が多い。

本実験では Cl-分泌機序解明の目的で，電解留 の転送に影暗を及ぼすといわれている各種薬物を 投与し，血液ならびに盟渡C1-濃度に及ぼす影響 を検語した。

Acetazolamide はH十転送に関与するCA阻害 薬といわれている。 Janowitz ${ }^{17}$ らはHeidenhain Pouckes犬に20mg/kg投与し, $\mathrm{HCl}$ の減少を認め, 胃液 $\mathrm{Cl} 一, \mathrm{Na}+, \mathrm{K} \div$ の变動は認めなからた. Texter, Mcgowana も $\mathrm{HCl}$ の減少を報告し，最近では Durbin ${ }^{18)}$ は胃液 $\mathrm{Cl}$-をacidic $\mathrm{Cl}^{-}$- none acidic $\mathrm{Cl}$ ーに分け，acetazolamide投与によりこれらが阻 害されることよりCl一- transportをも阻害すると報 告した. 本実験では臨床例でacetazolamide 500mg 投与で胃液おっび血夜 $\mathrm{Cl}$-濃度汇影響を認めず， acetazolamide $1000 \mathrm{mg}$ 投与で血液 $\mathrm{Cl}$ 一濃度の增加 を認め, 胃液 $\mathrm{Cl}$ 一蹗度は減少の傾向を喼めたにす

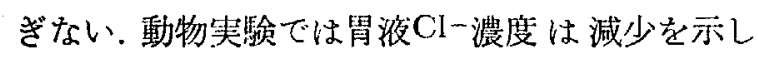
た。すなわら充分なacetazolamideの投与で鼠液 $\mathrm{Cl}$ 一濃度は減少を示与むの之思われる。

$\mathrm{Cl}$ 一がH+分泌になんら干涉を受けずに別の behavierkより輸送されるものと仮定すれば，C A阻害薬により $\mathrm{Cl}$-分泌は影響を受けないはずで あり,本実験結果とは一致をみない.すなわちC A 阻害薬により $\mathrm{Cl}$ 一分泌惊影を受け，それがH+分 泌阻害により $\mathrm{Cl}$-のpassive diffusionの阻害にあ

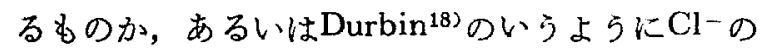
active transportの阻害作用がacetazolamideに あ るのかは明らかでない。

Chlorthalidone投与により血液 $\mathrm{Cl}$ 一浱度は減少 し，胃液Cl一濃度は平均值で減少の㖽向を示した にすぎず, $\mathrm{Cl}$ 一分泌一の影響は明らかでない。

Coopersteinはstrophanthidinで $\mathrm{Cl}^{-}, \mathrm{H}+$ carrier を阻害することを報笞し, Orloff ${ }^{19)}$ むtrophanthi$\operatorname{din} て ゙ \mathrm{H}^{+}, \mathrm{Cl}$ 一の抑制を報告した。本実験でouabain投与に上り霄液 $\mathrm{Cl}$ 一灌度の減少を認め, 血液 Cl一濃度に変動を認めない.このことからouabain が胃液のCl一分泌になんらかの抑制作用を示寸こ
とが推察される.

霄におけるCl一再吸収抑制学認める水銀利尿薬 について検馀した少，血浆 $\mathrm{Cl}$ 一濃度は臨床例，動 物例とも減少し，胃液 $\mathrm{Cl}$ 一濃度は動物例で減少を 示した。すなわら水銀利尿薬投与により血浆なら びに胃液 $\mathrm{Cl}$ 一漂度とも減少を示したので，胃液へ の影響は明らかでない。

副緊皮㗨ホルモン楽投与により，胃，十二指腸 潰瘍よりの出血，增悪化が報告されるようにな り，副腎と郦液分泌機能の関連性について注目を 浴びるようになつた。本东験でprednisolone投与 により一過性にglucocortcoid過剩状態を作り，胃

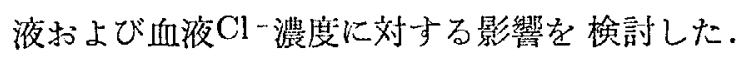
血液 $\mathrm{Cl}$ 一濃度は減少の傾向を示し, 胃液C1一濃度 はhistamine刺激後增加の傾问を認めた。

Welbournは幽門結禁ラットにcortisone 20mg 11日間投与でpH, 分泌量の增加を, cortisone $1 \mathrm{mg}$ 長 期間投与で減少を報告し，石田 ${ }^{201}$ はprednisolone を幽閏結紮ラットに1.5mg 6 日間，0.5mg 2 回投与 し，10時間の胃液分泌量，酸度の低下を誌めた。

Kyleはラットに対し cortisoneを投与し，罠液分 泌に影警を及ぼさないと報告した。こ礼ら実験は すべて幽阴結热ラットで7〜18時間の胃液の総和 についての報告で，必ずしも投与後の胃液の経時 的動態を論じたものではない。

電解質代謝をつかさどるといわれるmineral一 corticoidに対して拮抗作用を有するspironolactoneについて検討したが，血液ならびに胃液 $\mathrm{Cl}^{-}$ 濃度には影響を及洼さない上らである。

\section{v. 結 論}

血液拈よび胃液総 $\mathrm{Cl}$-灙度にか九して健康正常 者23例を含め各種疾患々者 302例につき，histamine刺激による態度を検討し，併せて各種薬物に よる影響を臨床的ならびに実験的に検討した。

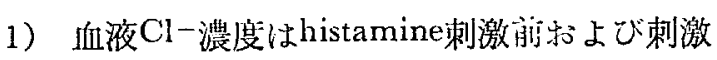
15分後の間で有意の変動を示さない．また基礎分 泌時血液 $\mathrm{Cl}$-濃度と胃液 $\mathrm{Cl}$ 一濃度の変動に有意性 を認めない。

2) histamine刺激に上り胃液 $\mathrm{Cl}$-濃度は增加 
し，その変動はhistamine投与量に比例して堌加 与るが，一力histamine $0.03 \mathrm{mg} / \mathrm{kg}<0.04 \mathrm{mg} / \mathrm{kg}$ 投 与群の変動に有意差を認めなかつた。

3）基碟分泌值 $\mathrm{Cl}$-濃度 と刺激後 $\mathrm{Cl}$ - 濃度は比 例して変動し, 基礎分泌值の高いものでは刺激後 $\mathrm{Cl}$-浱度も高い傾向を認めた。

4) histamnne刺激後 $\mathrm{Cl}$ - 最高反応時 $\mathrm{Cl}$-濃度で

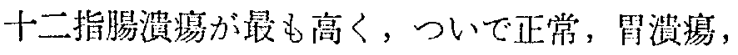
胃癌の順で低下し, 胃癌と他の疾患の間に差を認 めた。

5）胃カメラで胃溃㾤随伴性胃炎を 3 群に分け 胃液 $\mathrm{Cl}$ 一浱度を検討した。萎繀性胃炎高度のもの は胃液 $\mathrm{Cl}$-源度低く，莠縮性胃炎軽度，表在性胃 炎の順で高くなつた。

6）罠液 $\mathrm{Cl}-$ は $\mathrm{H}+, \mathrm{F}-\mathrm{HCl}$ と正の相関を， $\mathrm{Na}+$ は $\mathrm{H}^{+}, \mathrm{F}-\mathrm{HCl}$ と負の相関を認め, $\mathrm{Cl}-$ と $\mathrm{Na}+$ との 間には相関孛認めなからた。

7）胃液 $\mathrm{H}+/ \mathrm{Cl}$ 一此は刺激前後で有意の変動を 示さむ゙， $\mathrm{H}+$ 濃度の高いものでは此は高く, $\mathrm{H}+$ 濃 度の低いものは比子低い。

8）鼠液 $\mathrm{F}-\mathrm{HCl} / \mathrm{Cl}$-比は刺激後增加し, $\mathrm{H}+$ 濃 度の高いものでは此も高く， $\mathrm{H}+$ 濃度の低いもの では比も低く，胃潰瘍と胃癌の間に差を認めた。

9）胃液 $\mathrm{Cl}$ 一絶対量は $\mathrm{Cl}$ 一濃度之ほ 動を示した，疾患では溃癔例の变趿が激しく胃癌 で低值を示した。

10）acetazolamide投与で肙液 $\mathrm{Cl}$-濃度は動物例 で減少し，臨床例では血浆 $\mathrm{Cl}$ 一濃度の増加を認め た。

11） chlorthalidone投与 で血浆 $\mathrm{Cl}$-濃度は減少 し, 胃液 $\mathrm{Cl}$-濃度はhistamine刺激後減少の傾向を
認めた。

12）prednisolone投与で胃液 $\mathrm{Cl}$-濃度はhistamine刺激後增加の傾向を認めた。

13）水銀利尿薬投与で動物例，臨床例々も，血 浆 $\mathrm{Cl}$-濃度は減少し, 胃液 $\mathrm{Cl}$ 一濃度は動物例で減少 を認めた

14）ouabain投与で留液 $\mathrm{Cl}$-濃度は減少した。

15）spironolactone投与で血液ならびに胃夜

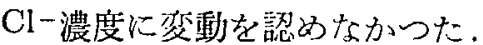

\section{参考文解}

1) Davenport, H.W.: J. Physiol. (Lond), 97 : 32, 1939. -2) Rosemann, R.: Pfügers Arch. ges. Physiol., 118:467, 1907. -3) Hogben, C. A.M.: Amer. J. Physiol., $180: 641$, 1955. -4) Cooperstein, I.L.: J. gen. Physiol., $42: 1233$, 1959. -5) Kay, A.W.: Brit. med. J., $11: 77$, 1953，一6）忠田守喜：日消誌，62：957，1965，一 7) Lambling, A. et Bernier, J.: J. Arch, Mal. Appar. dig., 42 : 57, 1953. -8) 大井実 : 最新医 学, $11: 297,1956 .-9)$ Hirschowitz, B.I. et al.: J. Lab. clin. Med., $50: 447,1957$, -10) Hollander, F.: Fed. Proc., $11: 706,1952$. - 11) Conway, E.J.: Science, $113: 270,1951$. -12) Davies, R.E. and Ogston, A.G.: Biochem. J., 46 : 324, 1950. -13) Nielsen, S.O. and Rosenberg, T.: Compt. rend. d. trav. du. Lab. Carlsberg. serie chim., $27: 437,1951 .-14$ ) Obrink, K. J.: Acta physiol. scand, 16 : Suppl. 53, 1948. -15) Hogben, C.A.M.: Proc. nat. Acad. Sci. (Wash.), $38: 13,1952$. -16) Rhem, W.S.: Fed. Proc., $9: 105,1950$. --17) Janowitz, H.D., Colcher, H., and Hollander, F.: Amer. J. Physiol., $171: 325,1952$. - 18) Durbin, R.P. and Heinz, E.: J. gen. Physiol., 41 : 1035, 1958. -19) Orloff, J. and Burg, M.: Amer. J. Med., $25: 129$, 1958, 一20) 石田哲载：岡山医学会雑誌，71。 B : 1509,1959 . 